Pace University

DigitalCommons@Pace

2015

\title{
More Than A Woman: Insights into Corporate Governance After the French Sex Quota
}

Darren Rosenblum

Elisabeth Haub School of Law at Pace University

Follow this and additional works at: https://digitalcommons.pace.edu/lawfaculty

Part of the Business Organizations Law Commons, Comparative and Foreign Law Commons, and the Law and Gender Commons

\section{Recommended Citation}

Darren Rosenblum \& Daria Roithmayr, More Than a Woman: Insights into Corporate Governance After the French Sex Quota, 48 Ind. L. Rev. 889 (2015), http://digitalcommons.pace.edu/lawfaculty/993/.

This Article is brought to you for free and open access by the School of Law at DigitalCommons@Pace. It has been accepted for inclusion in Pace Law Faculty Publications by an authorized administrator of DigitalCommons@Pace. For more information, please contact dheller2@law.pace.edu. 


\title{
MORE THAN A WOMAN: INSIGHTS INTO CORPORATE Governance AFTer THE French SeX QuOTA
}

\author{
DARREN ROSENBLUM* \\ DARIA ROITHMAYR ${ }^{* *} \phi$
}

\begin{abstract}
In 2011, France enacted a Corporate Board Quota to establish a forty percent floor for either sex on corporate boards. Existing literature presumes that women will change the way firms function and that their presence in upper management will improve both governance and financial returns. To assess the potential impact of the quota, we interviewed twenty-four current and former corporate board members. Our analysis of these interviews generates two findings. First, our results indicate that, at least in the view of board members, the sex quota has had an impact on the process of board decision-making, but adding women has not affected the substance of decision-making. Second, our findings suggest for the first time that adding women to a board may well have a substantive impact on decision-making, not because the newly added members are women but rather because they are more likely to be outsiders. French participants reported that newly added female members affected substantive decision-making because they were more likely to be foreign, to be expert in a wider range of areas, and to be drawn from non-elite networks than their male counterparts.
\end{abstract}

\section{INTRODUCTION}

In early 2011, France adopted a law that requires men and women each have at least forty percent representation on corporate boards. ${ }^{1}$ This quota compels

* Professor, Pace University Law School.

** George T. and Harriet E. Pfleger Professor of Law, University of Southern California Gould School of Law.

$\phi$ This research was supported by the Fulbright Research Scholarship, awarded to Darren Rosenblum in 2011. Thanks to Matthew Collibee, Briana Costa, Christopher Croll, David Restrepo, Nicolas Tapert, Katie Waitman, and Adam Weiss for their research support and assistance. This project benefited from support by the Commission Franco-Américaine and from comments during faculty workshops at American University Washington College of Law, Hofstra University School of Law, the University of Utah Law School, Sciences Po Law School, the University of Chicago Law School Workshop on Regulating Family, Sex and Gender, the AALS Sections on Business Associations, Comparative Law, and Economic Globalization and Governance Law, the Global Governance Programme of the European University Institute, and Pace Law School's “Comparative Sex Regimes and Corporate Boards” Symposium.

1. Loi 2011-103 du 27 janvier 2011 relative à la représentation équilibrée des femmes et des hommes au sein des conseils d'administration et de surveillance et à l'égalité professionnelle [Law 2011-103 of January 27, 2011, on the Balanced Representation of Women and Men on Board of Directors and Supervisory Boards and Equality Professional], JOURNAL OFFICIEL DE LA RÉPUBLIQUE FranÇAISE [OFFICIAL GAZETTE OF FrANCE], Jan. 28, 2011 [hereinafter J.O.]. 
mixité (roughly translated to mean sex diversity) ${ }^{2}$ for over two thousand publicly traded companies in France.

France is the largest country to have adopted such a quota, but by no means is it the first. ${ }^{3}$ Norway adopted a quota in 2003 requiring a floor of forty percent for either sex resulting in universal compliance in 2008. ${ }^{4}$ Since France's adoption, several other European countries have followed suit, including most notably Germany. ${ }^{5}$ Likewise, the European Union is currently debating whether to adopt a quota. ${ }^{6}$ Even in the United States, where libertarian notions of property and resistance to affirmative action have undermined any interest in quotas, ${ }^{7}$ the European move has triggered a debate over the need for greater sex diversity in upper management.

This project constitutes a preliminary study to investigate whether and how the French quota has affected corporate governance in CAC-40 firms, France's largest firms. ${ }^{8}$ We interviewed twenty-four members of these firms'

2. Mixité is a French term meaning sex diversity, but the "mixing" implies a mixing of the two sexes. The use of this distinct term reflects a central distinction drawn in the French context, even as diversity remains central in the United States. While mixité refers to a clear binary of male/female that is widely accepted in France, diversity carries a broader meaning in the United States. We use "sex" rather than "gender" because the quota's key determination of who belongs on boards mandates a binarist distinction between men and women, rather than a more fluid framework.

3. Aaron Dhir, Challenging Boardroom Homogeneity: Corporate law, GOVERNANCE AND Diversity (2015); see, e.g., Nicola Clark, Getting Women Into Boardrooms, by Law, N.Y. TIMES (Jan. 27, 2010), http://www.nytimes.com/2010/01/28/world/europe/28ihtquota.html?pagewanted=all\&_r=0, archived at http://perma.cc/FEA3-M89M (explaining that Norway adopted a quota in 2003).

4. See Clark, supra note 3.

5. David A. Matsa \& Amalia R. Miller, A Female Style in Corporate Leadership? Evidence from Quotas, 5 Am. ECON. J.: ApPLIED ECON. 136, 137 n.5 (2013); see also EUROPEAN Commission, Positive Action Measures to Ensure Full Equality in Practice Between Men AND WOMEN, INCLUDING ON COMPANY BOARDS (2012); James Kanter, E.U. Considers Quotas for Women in Boardrooms, N.Y. TIMES (Mar. 4, 2012), http://www.nytimes.com/ 2012/03/05/business/global/eu-considers-quotas-for-women-in-boardrooms.html?pagewanted=all, archived at http://perma.cc/EB9K-ZS6U; Alison Smale \& Claire Cain Miller, Germany Sets Gender Quota in Boardrooms, N.Y. TIMES (Mar. 6, 2015), http://www.nytimes.com/2015/03/07/ world/europe/german-law-requires-more-women-on-corporate-boards.html?_r=0, archived at http://perma.cc/WUZ5-8G4P.

6. See Kanter, supra note 5.

7. See Darren Rosenblum, Parity/Disparity: Electoral Gender Inequality on the Tightrope of Liberal Constitutional Traditions, 39 U.C. DAVIS L. REV. 1119, 1174-78 (2005).

8. The CAC-40 is the French equivalent of the Dow Jones Industrial Average. It is a group of forty of the largest and most prominent publicly traded corporations listed on the Paris Stock Exchange. Structure $d u$ Marché Français [French Market Structure], ABCBouRSE, http://www.abcbourse.com/apprendre/1_plusiers_marches.html (last visited Aug. 13, 2014), archived at http://perma.cc/R3NZ-MPGQ. Among these leading French firms are some that date 
boards - eleven male and thirteen female - drawn from thirteen of the forty CAC-40 firms. ${ }^{9}$ We interviewed seven additional subjects: two civil society leaders, two legislators, two recruiters, one coach, and one non-CAC-40 board member. ${ }^{10}$ Interviews included a range of questions designed to assess the effect of the quota and of the increased presence of women on corporate governance. ${ }^{11}$

Analyzing the interview results enables us to offer two preliminary findings on the effect of the quota on corporate governance in France. First, we find that, at least in the view of corporate board members themselves, the quota has not substantively affected corporate governance decisions, nor is it likely to do so. Although sex composition of boards has changed, ${ }^{12}$ and in some instances decision-making processes have changed, in the view of board member participants, board decisions have not changed substantively because of sex.

Second, and importantly, our findings suggest that the quota has in fact had a substantive impact, but not because of the sex of newly added board members. Rather, our interview results suggest that in the view of board members, newly added female members have had a substantive impact on corporate governance because they are outsiders. For strategic reasons that we explore below, to comply with the quota, French boards have appointed women members who are more likely to be foreign, from non-elite professional and educational networks, less experienced and from specialties not traditionally represented on boards, like environment or labor. Participants suggest that these traits, which are associated with women's outsider and newcomer status and not their sex, are potentially

back to the seventeenth century, as well as firms of much more recent vintage, global banks, industrial conglomerates, firms that rely exclusively on private capital, companies with a heavy participation by the state, and even a few old-fashioned, family-owned businesses. See generally James A. Fanto, The Role of Corporate Law in French Corporate Governance, 31 CoRNELL INT'L L.J. 31 (1998).

9. Darren Rosenblum organized and conducted all interviews.

10. Several others in France helped prepare the project design, including professors and one CAC-40 in-house counsel.

11. Methodological challenges include comparative issues in delving into another country's cultural and legal realities. See infra Part III. In addition, the problem of researching corporate boards surfaces as a substantial impediment to any study. The secrecy of corporate governance and strategy make access difficult and direct observation impossible. Board members in such large firms are often former executives who are extraordinarily unavailable for research investigation.

12. A study by the Ethics \& Boards Observatory found that CAC- 40 firms have increased the percentage of women on their boards to twenty-eight percent. Post Assemblées Générales 2013: Les Femmes dans les Conseils du CAC 40 Au 25 Juin 2013 [Post General Meetings 2013: Women in the Boards of the CAC 40 at June 25, 2013], ETHICs \& BOARDS (June 25, 2013). The French corporate board quota ("FCBQ") requires a twenty percent rate of each sex by 2014. See supra note 2. While companies have been able to comply thus far, filling in the remaining women necessary under the quota may prove more challenging. Julien Bonnet, Conseils d'Administration: Où Sont les Femmes? [Board of Directors: Where are the Women?], L'Usine NouvELLE (Feb. 12, 2013), http://www.usinenouvelle.com/article/conseils-d-administration-ou-sont-les-femmes. N191458, archived at http://perma.cc/44MZ-QL7U. 
responsible for any difference in substantive board decision-making after the quota.

Our study contributes to a small body of literature that assesses the impact of sex on governance from the perspective of corporate board members using qualitative interviews. ${ }^{13}$ Broome, Conley, and Krawiec ${ }^{14}$ interviewed United States board members, asking them to give examples of how gender mattered; from subjects' difficulty in doing so, the team concluded that gender has had little effect on corporate governance. ${ }^{15}$ Likewise, Conley et al. concluded in a set of projects that the evidence from qualitative interviews for gender's impact on governance is thin: board members cannot produce concrete examples of how and when diversity matters ${ }^{16}$ and according to participants, even boards that maintain or achieve a critical mass of women do not produce distinctly feminine process or substantive outcomes, like collaborative decision-making or familyfriendly work policies. ${ }^{17}$

Aaron Dhir's work on the Norway quota ${ }^{18}$ reaches a different conclusion. Dhir finds support for the idea that gender makes a difference in corporate governance, as participants report changes in the process of board meetings. Dhir's subjects trace these differences to gender, though many of the differences they report are also linked to the newcomers' outsider status.

This study makes several original contributions to the literature. Initially, our study is the first to interview participants from France, which like Norway, has actually adopted a formal quota requiring firms to add women to their boards. In comparison to boards in the United States, which regulate themselves voluntarily, French boards have legally been forced to grapple with the specific issue of sex far more directly. ${ }^{19}$ Because women are entering corporate French firms in unprecedented numbers, the link between sex and corporate performance/governance has become far more salient for French board members, making their observations more specific, and therefore more useful for understanding the link between sex and corporate performance.

13. Our study also has a markedly distinct focus from United States literature on the French corporate board quota. For example, Julie Suk emphasizes the central role played by the corporatist tradition in the passage of the law in France and the way in which the law functions to legitimize the democratic state. See Julie C. Suk, Gender Parity and State Legitimacy: From Public Office to Corporate Boards, 10 InT'L J. CONST. L. 449 (2012).

14. See, e.g., John M. Conley et al., Narratives of Diversity in the Corporate Boardroom: What Corporate Insiders Say About Why Diversity Matters, DisCOURSE PERSPECTIVES ON Organizational CommC'N (2010); see also Lissa L. Broome et al., Dangerous Categories: Narratives of Corporate Board Diversity, 89 N.C. L. REV. 759 (2011).

15. Conley et al., supra note 14; Broome et al., supra note 14.

16. See, e.g., Conley et al., supra note 14; Broome et al., supra note 14.

17. Lissa L. Broome et al., Does Critical Mass Matter? Views From The Boardroom, 34 Seattle U. L. ReV. 1049, 1080 (2011).

18. DHIR, supra note 3.

19. Barbara Black, Protecting the Retail Investor in an Age of Financial Uncertainty, $42 \mathrm{U}$. DAYTON L. REV. 61, 77-78 (2009). 
Second, our work is among the first to assess the impact of the corporate quota specifically among large firms, which traditionally resist equality-driven legal mandates including those relating to sex; Dhir's work on the Norway quota focused on small firms. Analysis of change at the CAC-40 firm - the most elite firms in France - provides a useful point of comparison for purposes of exploring the potential impact of legal regulation in the United States, even as the elite nature of these firms may be relatively unrepresentative, and the cultural and legal differences with the United States potentially significant. ${ }^{20}$

This Article will proceed in five parts. In Part I, we provide the context for our investigation by briefly reviewing the history of the French quota's enactment. Part II reviews the theoretical literature on the effect of sex on corporate board decision-making. Most existing literature suggests that a critical mass of women on corporate boards will improve corporate governance and the firms' overall performance.

In Part III, we briefly describe the methodology used to obtain and conduct interviews and to carry out the analysis. Part IV describes the original individual interview data collected from current and former members of corporate boards from CAC-40 firms. In Part V, we analyze our results. Our analysis of the data shows that the French quota likely has little effect on board decision-making substantively, though it appears at least from the board's perspective to affect the process by which boards arrive at decisions. Part V also discusses the important finding that whatever effect sex diversity might have on corporate decisionmaking might in fact be traceable to the new members' outsider status and nontraditional experience.

\section{HISTORY OF FRENCH QUOTA}

\section{A. Parity and Pressure}

The corporate board quota is not the first time that France has used a sex quota. $^{21}$ In 2000, the French legislature enacted the parity law, which requires political parties to name women as half of all candidates. ${ }^{22}$ Feminists and Socialists led the push for parity to remedy the chronic lack of women representatives in positions of political power. The legislature's earliest efforts to enact parity were met with rejection by the Constitutional Council, which is authorized to review enacted laws prior to their implementation. ${ }^{23}$ In response

20. Any comparison between corporate regulation in the United States and France requires greater attention to substantive differences between the two legal cultures. See generally Fanto, supra note 8.

21. See, e.g., ELEONORE LÉPINARD, L'EGALITÉ INTROUVABLE; LA PARITÉ, LES FEMINISTS ET LA RÉPUBLIQUE [Impossible-to-Find Equality; Parity, Feminists and the Republic] (2007); JOAN WALLACH SCOTT, PARITY! (2005); Rosenblum, supra note 7, at 1123.

22. LÉPINARD, supra note 21; WALLACH SCOTT, supra note 21; Rosenblum, supra note 7, at 1123.

23. Suk, supra note 13. 
to the council's decision, the legislature, through a supermajority, amended the French constitution, which paved the way for subsequent enactment of the parity quota. Although the parity law did not achieve the gains its drafters and feminist advocates had promised, the quota opened the door to the use of the quota in the context of corporate governance. ${ }^{24}$

French interest in a corporate board quota developed after Norway adopted its quota in 2003..$^{25}$ As of 2009, only ten percent of the directors of French listed companies were female, and five percent of new board members were women, well below the level of other countries. ${ }^{26}$ Only four publicly listed companies had reached the twenty percent threshold. ${ }^{27}$ Private sector attempts at selfregulation failed to forestall the quota's advance. ${ }^{28}$ Proponents of the quota took substantial notice of the quota's success in Norway, which adopted a corporate board requirement of forty percent in $2003 .^{29}$

\section{LÉPINARD, supra note 21.}

25. See, e.g., Clark, supra note 3 (describing Norway's adoption of a quota in 2003); DHIR, supra note 3.

26. See François Roche, Conseils d'Administration: les Femmes Investissent le CAC 40 [Board of Directors: Women Join the CAC 40], LA TRIBUNE (July 15, 2011), http://www. latribune.fr/actualites/economie/france/20110715trib000636534/conseils-d-administration-lesfemmes-investissent-le-cac-40.html, archived at http://perma.cc/UN59-ZH2T; Institut Français des Administrateurs, Journée Annuelle des Administrateurs 2010: les Nouvelles Dynamiques du Conseil [Annual Day of Directors 2010: Dynamic News Board], 21 ADMINISTRATEUR: LA LETTRE DE L'IFA 1, 3 (2010); Veronique Morali, Les Femmes dans les Conseils d'Administration [Women in the Board of Directors], LA GOUVERNANCE DES ENTREPRISES, CLÉ DE LA COMPÉTIVITÉ 24 n.409 (2011).

27. Institut Français des Administrateurs, supra note 26.

28. Since 1995 several business groups have produced effective corporate governance codes, to which listed companies may voluntarily refer. These include Viénot Reports one and two, the Bouton Report, and the AFEP-MEDEF Report. The "Association française des entreprises privées" ("AFEP") and the "Mouvement des entreprises françaises" ("MEDEF") are the two leading professional associations for private companies in France. Now the code of reference for companies issuing shares admitted to trading on a regulated market, the AFEP/MEDEF Code established in April 2010 certain parity objectives to be achieved progressively for women on boards of "at least twenty percent female directors within three years and at least forty percent within six years." The AFEP/MEDEF Code may also apply to companies outside the FCBQ's scope. All these reports were combined in a code, the code of corporate governance for listing companies. See Code de d'Entreprise des Sociétés Cotées [Corporate Code of Listed Companies], AFEP (June 2013). However, European Community law obligates the chair of the board of directors (or supervisory board) to prepare a report on corporate governance, including whether the firm complies with the AFEP/MEDEF code. Non-compliance requires explanation. The French Financial Markets Authority (l'Autorité des marchés financiers, “AMF”) then publishes an annual report that includes firms' internal monitoring procedures. See also Veronique Magnier \& Darren Rosenblum, Quotas and the Transatlantic Divergence of Corporate Governance, 34 NW. U. L. REV. 249 (2014).

29. Interview with $25 \mathrm{~F}$; interviews will be referred to by an identification number and $\mathrm{M}$ or 
Leading the push for the corporate board quota was the conservative Union pour la Majorité Parlementaire ("UMP") Party, led by then-President Nicolas Sarkozy. ${ }^{30}$ Observing the lack of progress in women's inclusion in the corporate hierarchy, conservatives proposed a quota even as business signaled resistance to this form of remedy. In response to efforts by private sector leaders to forestall public legislation with voluntary measures, ${ }^{31}$ co-sponsor of the quota, Marie-Jo Zimmerman, opined that a quota was necessary to "get things to move." 32

Conservative focus on sex was largely strategic: the push for the quota came at the same time that conservatives had moved to ban burqas and were trying to ban the wearing of long skirts. ${ }^{33}$ By modernizing the corporate boardroom to include women, conservatives could more comfortably take a position against "backward" practices such as traditional Muslim dress. ${ }^{34}$ Indeed, conservative leader Jean-François Copé remarked in a public speech at a Paris colloquium that "[t]he test of a society's civilization is in how it treats its women." 35

Beyond conservatives, a range of stakeholders-government, labor, and others-supported the quota. Public debate included reference to foreign

F to indicate sex; see infra note 83.

30. One participant labeled Sarkozy as "a big feminist;" another, a legislator, said the opposite. See Interviews with $14 \mathrm{~F}$ and $25 \mathrm{~F}$.

31. La Quasi-Parité Imposée au Sein des Conseils d'Administration [The Quasi-Parity Imposed on the Boards of Directors], LES ECHOS (Feb. 21, 2011), http://archives.lesechos.fr/ archives/cercle/2011/02/21/cercle_33475.htm\#, archived at http://perma.cc/X64B-XHKY [hereinafter Les ECHOS]; François Lenglet, Medef et Afep Promeuvent la Parité dans les Conseils [Medef and Afep Promote Parity in the Boards], LA TRIBUnE (Apr. 19, 2010), http://www. latribune.fr/journal/edition-du-2004/politique-france/405290/medef-et-afep-promeuvent-la-paritedans-les-conseils.html, archived at http://perma.cc/VX96-JPYQ; see also Medefet Afep Promettent Plus de Femmes dans les Conseils d'Administration [Medef and Afep Promise More Women in Boards of Directors], L'EXPRESS (Apr. 20, 2010), http://lexpansion.lexpress.fr/ actualiteeconomique/medef-et-afep-promettent-plus-de-femmes-dans-les-conseils-dadministration_1339420.html, archived at http://perma.cc/97EL-D5BF.

32. Olivier Auguste, Les Grandes Entreprises Promettent la Parité [Large Companies Promise Parity], LE FigARO (Apr. 19, 2010), http://www.lefigaro.fr/entreprise/2010/04/19/0501120100419ARTFIG00680-les-grandes-entreprises-promettent-la-parite-.php?pagination=2, archived at http://perma.cc/QN4T-NMEA.

33. Kim Willsher, French Muslim Women on Burqa Ban Ruling: 'All I Want Is to Live in Peace, 'The GuARDian (July 1, 2014, 2:26 PM), http://www.theguardian.com/world/2014/jul/01/ french-muslim-women-burqa-ban-ruling, archived at http://perma.cc/H8LH-YRDW.

34. Id.

35. Jean-François Copé, remarks at "Les femmes au conseil d'administration: ça change quoi?" (Women on Boards: What Changes?) at the Association France-Amerique in Paris, France (Sept. 26, 2011). See Événements Récents [Recent Events], FRANCE-AMÉRIQUES, http://www. france-ameriques.org/2011.html (last visited Aug. 13, 2014), archived at http://perma.cc/JM3UKQGC. 
progress, including that achieved in Norway. ${ }^{36}$ Jean Luc Châtel, the French Press Secretary, signaled the Administration's grudging agreement, noting that "the quota is not necessarily the best solution, but at the same time we perceive that if we do not legislate, we will have a hard time obtaining results."37

Some policymakers argued that the corporate board was not the proper institution to require change. For example, former Minister of Labor Xavier Darcos suggested that the quota should mandate the addition of women to executive committees, arguing that this is where a firm's real decisions are made. ${ }^{38}$ Darcos predicted that a board quota would not change much in the way of corporate governance. ${ }^{39}$

Not surprisingly, members of the business community raised an objection to the quota. ${ }^{40}$ In a conversation among thirteen women directors assessing the

36. As a general matter, European firms in general, and French firms in particular, already tend to include stakeholder perspectives more fully when compared to firms in the United States. This pro-stakeholder perspective can be traced both to French corporatist traditions, in which the state continues to play a more central role in the corporate sector, and to the fact that workers are represented on the board. See Magnier \& Rosenblum, supra note 27; see also Viviane Reding, Quota Français pour les Conseils d'Administration: Pourquoi Pas? [French Quota for the Boards of Directors: Why Not?], LES ECHOS (Mar. 3, 2011), http://www.lesechos.fr/01/03/2011/ LesEchos/20880-091-ECH_quotas-de-femmes-dans-les-conseils---pourquoi-pas-.htm?texte=Quota $\% 20$ Fran $\%$ C3\%A7ais $\% 20$ pour $\% 201$ es $\% 20$ Conseils $\% 20 \mathrm{~d} \%$ E2\%80\%99Admin istration:\%20Pouhttp://www.lesechos.fr/01/03/2011/LesEchos/20880-091-ECH_quotas-defemmes-dans-les-conseils---pourquoi-pas--.htm?texte=Quota $\% 20$ Fran $\% \mathrm{C} 3 \%$ A 7 ais $\% 20$ pour\% 201es\%20Conseils\%20d\%E2\%80\%99Administration:\%20Pourquoi\%20Pas?rquoi\%20Pas?, archived at http://perma.cc/6XKH-28A5. The article noted that many countries in the E.U. have taken the measures to help women to get a high position in European society. Id. In Norway, which adopted a quota in 2003, as of 2009, forty-two percent of the boards were women. Id.

37. Marion Lippman, Quotas de Femmes: le Débat Demeure Vif [Quotas for Women: The Debate is Still Alive], 20MINUTES.FR (Oct. 29, 2009), http://www.20minutes.fr/economie/561985unpublished-economie-quotas-de-femmes-le-debat-demeure-vif, archived at http://perma.cc/ MQ35-YDQS. Even Laurence Parisot, the leader of the organization of top corporations, L'Association Française Des Entreprises Priveés, admitted that "One cannot like quotas, but there are circumstances where a thumb on the scale can unblock the situation." See also Auguste, supra note 32 .

38. "It would be much more interesting to know how women will be represented in the Executive Committee, where decisions are really made." Lippman, supra note 37 (quoting Xavier Darcos).

39. "The board of directors is the organ that represents shareholders . . . one can put more women there, but if the majority shareholder puts men and the minority shareholders are represented by women, that will not change much." Id. (quoting Xavier Darcos, lors d'un déplacement à Rueil-Malmaison (Hauts-de-Seine), au siège du groupe Schneider Electric).

40. See, e.g., Yann Le Galès, Quotas: 13 Dirigeantes Jugent la Loi Qui Impose des Femmes dans les Conseils d'Administration [Quotas: 13 Leaders Believe the Law Requires Women on the Boards of Directors], LE FIGARO (Jan. 19, 2010), http://blog.lefigaro.fr/legales/2010/01/ conseilsdadministration-10-femmes-jugent-la-loi.html, archived at http://perma.cc/R2HT-XYZU. 
proposed law, a well-known woman director, Patricia Barbizet, claimed that quotas would necessarily be ineffective, because they would not produce any change in people's attitudes and a mandatory requirement would stigmatize women. ${ }^{41}$ Likewise, a number of academics argued that shareholders and administrators should choose whether to add women, free from legislative mandate. ${ }^{42}$ In their view, "competence," not sex, was what mattered. ${ }^{43}$

The legislature first adopted a corporate sex quota in 2006, but the Constitutional Council struck it down, notwithstanding the Constitutional amendment that had enabled the parity quota to be enacted. ${ }^{44}$ The Council considered quotas in the corporate context to be a separate issue from the parity quota, which had required sex parity in political representation. ${ }^{45}$ In response to the court's decision, the legislature passed yet another constitutional amendment in 2008 to permit private quotas to promote women "to positions of professional and social responsibility." ${ }^{46}$ In addition, lawmakers also inserted Article 1, which "essentially established the duty to promote [sex] parity as fundamental constitutional law." 47

\section{B. The Quota}

Law 2011-103 (January 27, 2011) ${ }^{48}$ was entitled "On the equal representation of men and women on boards of directors and supervisory boards and professional equality." ${ }^{49}$ In drafting what would become the final law, conservative lawmakers replicated many features of the Norwegian quota. ${ }^{50}$ The

41. Id.

42. François-Xavier Lucas, Bulletin Joly Sociétés, Nov. 1, 2009 n.11, p. 945.

43. Id.

44. Suk, supra note 13 (citing Conseil constiutionnel [CC] [Constitutional Court] decision No. 2006-533DC, Mar. 16, 2006, Rec. 39 (Fr.), Loi relative à l'égalité salariale entre les femmes et les hommes) (based on Article 3 of the Constitution and Article 6 of the Declaration of Rights of Man).

45. Id.

46. Id. (citing J.O., supra note 1).

47. Id.

48. J.O., supra note 1.

49. See Roche, supra note 26; see also LES ECHOS, supra note 31.

50. Aagoth Storvik \& Mari Teigen, Women on Board: The Norwegian Experience, FRIEDRICHEBERT STIFTUNG 1, 4 (2010); Rules Regarding Gender Balance Within Boards of Public Limited Companies, REgJERINGEN.NO (Dec. 20, 2005) [hereinafter REGJERINGEN.NO]. Norway's Companies Act, amended in 2003, now reads:

$\S 6-11 \mathrm{a}$. Requirement regarding the representation of both sexes on the board of directors (1) On the board of directors of public . . . companies, both sexes shall be represented in the following manner:

1. If the board of directors has two or three members, both sexes shall be represented.

2. If the board of directors has four or five members, each sex shall be represented by at least two.

3. If the board of directors has six to eight members, each sex shall be represented by 
law established the principle that boards of directors, supervisory boards of private companies or joint-stock companies of any size, listed and unlisted, must strive for an equal representation of men and women. ${ }^{51}$ Framed not as a sexspecific quota but a floor for both sexes, the law required boards of directors, supervisory boards of private companies or joint-stock companies of any size, listed and unlisted, to strive for an equal representation of men and women. ${ }^{52}$

The legislation established minimum percentages to be met and a schedule for attaining these objectives: a twenty percent minimum for both sexes by 2014 and forty percent by $2016 .{ }^{53}$ Firms subject to the requirement included (i) private companies and joint-stock companies issuing shares and admitted for trading on a regulated market and (ii) French corporations that, for three consecutive fiscal years, employed at least 500 permanent staff members and produced an annual revenue or balance sheet total of at least $€ 50$ million. ${ }^{54}$

Sanctions against non-compliant firms were designed to be swift and significant: non-compliant firms faced the revocation of non-compliant nomination $s^{55}$ and the possibility of freezing board members' fees. ${ }^{56}$ The French quota stopped short of the Norwegian penalty of dissolution for non-compliant firms. ${ }^{57}$ The French law required firms to comply with the quota in two stages: regulations mandated that firms have at least twenty percent women by January 1,2014 and the full forty percent by January 1, 2017.

at least three.

4. If the board of directors has nine members, each sex shall be represented by at least four, and if the board of directors has more members, each sex shall be represented by at least 40 percent.

5. The rules in no. 1 to 4 apply correspondingly for elections of deputy directors.

51. CODE DE COMMERCE [C. COM.] arts. L225-17, L225-69, L226-4 (Fr.).

52. Id.

53. See Magnier \& Rosenblum, supra note 28 , at 25.

54. Id.

55. Article 6 of the Act Number 2011-103 from 27th January 2011 provides:

III. In public establishments and companies ... the proportion of members of the board of directors or of surveillance of each sex named . . . cannot be inferior to [twenty percent] counting from the first renewal following the publication of this law. When one of the two sexes is not represented inside the board of directors or of surveillance at the date of the publication of this law, at least one representative of this sex should be named on the next vacancy ... Any nomination in violation of [the above] and not having for effect to remedy the irregularity of the composition of the board of directors or of surveillance is void.

J.O., supra note 1.

56. Article 1 of the Act Number 2011-103 from 27th January 2011 provides: "When a board of directors is not composed conforming to [this statute] the planned payment of salary is suspended. The payment is reestablished when the composition of the board of directors becomes regular." Article 1 of the Act Number 2011-103 from 27th January 2011.

57. REGJERINGEN.NO, supra note 50. 


\section{Quota Compliance}

The FCBQ's passage had an immediate effect. ${ }^{58}$ Although the first deadline was three years away, firms of all sizes sharply increased their levels of women's representation. ${ }^{59}$ When the bill was introduced, nominations from general meetings in 2010 doubled their existing percentages of women; almost a third of new directors proposed were women, and thirty percent of CAC-40 companies had reached the FCBQ's twenty percent intermediate level by $2010 .^{60}$ This immediate reaction was strategic: firms wanted to secure the membership of the most "competent" women for their boards before other firms came calling. ${ }^{61}$

From preliminary information available, it appears that compliance for the 2014 deadline is quite high $^{62}$ - France's Minister for Women's Rights has reported over thirty percent women on CAC-40 boards and $28.8 \%$ in the larger SBF-120 group of French firms. ${ }^{63}$ Seven of the top ten global firms with high levels of women's representation are French. ${ }^{64}$ Firms now have set their sights on meeting the forty percent deadline in 2017 , though there are some concerns

58. A study done by Fédération des Femmes Administrateurs found that as of 2013, there was an average of $26.6 \%$ of women with CAC- 40 companies' boards and $24.7 \%$ of women within SBF120 companies' boards. In addition, there was an average of four women on CAC-40 companies' boards and three women on SBF-120 companies' boards. Of the SBF-120 companies, two-thirds of the companies had between twenty percent and forty percent of women on their boards, five percent exceeded forty percent of women on their boards, and eighty-three percent of women held only one directorship. Karima Bouaiss \& Agnes Bricard, Femmes Administrateurs dans le SBF 120 en 2013: Un État des Lieux [Women Directors in the SBF120 in 2013: An Inventory], ASSOCIATION DES FEMMES DIPLÔMÉES D'EXPERTISE COMPTABLE ADMINISTRATEURS (“AFECA”), 2014, at 1-29, available at http://www.federation-femmes-administrateurs.com/wpcontent/uploads/2014/02/les-femmes-administrateurs-au-sein-des-conseils-dadministration-dessocietes-du-sbf-120-en-2013.pdf, archived at http://perma.cc/29N5-LR4R.

59. Id.

60. Institut Français des Administrateurs, supra note 26.

61. Interview with $18 \mathrm{~F}$.

62. See supra note 58.

63. Najat Vallaud-Belkacem, La Part des Femmes dans les CA du CAC40 Dépasse 30\%[The Proportion of Women Within CAC40 Companies' Boards Exceeds Thirty Percent], LE MONDE (June 6, 2014), available at http://www.lemonde.fr/economie/article/2014/06/05/la-part-desfemmes-dans-les-ca-du-cac-40-depasse-30_4432274_3234.html, archived at $\mathrm{http}: / /$ perma.cc/Y3K4TT3S.

64. Corporate Women Directors International ("CWDI") recently issued a study showing that among the 200 biggest companies in the world, ranked according to the proportion of women within boards, seven French firms rank in the top ten (SG, BNP Paribas, AXA, Total, GDF Suez, Peugeot, Saint Gobain); see Tara Deronzier, La France est le Pays Qui Compte le Plus de Femmes Dirigeantes [France is the Country with the Most Women Leaders], FocUSUR.FR (June 13, 2014), available at $\mathrm{http}: / / \mathrm{www}$.focusur.fr/actualites/2014/06/13/la-france-est-le-pays-qui-compte-le-defemmes-dirigeantes, archived at http://perma.cc/6MTP-N4H8. 
regarding compliance for smaller firms. ${ }^{65}$ Firm recruiting practices have also begun to transform in the wake of the quota: the majority of board members report that their organizations have now begun to use executive search firms in choosing new board members, male and female. ${ }^{66}$

\section{The CASE FOR AND Against QuOTAS}

\section{A. Empirical Links Between Sex and Performance}

Much debate about sex quotas has centered on the "business case" for quotas. A body of empirical research suggests that firms with women in leadership positions generate higher profits, return-on-equity, share prices, or other financial benefits for a firm. ${ }^{67}$ These studies focus primarily on the firm's return on equity and other financial yardsticks of performance ${ }^{68}$ A widely-cited 2007 study by Catalyst, Inc., a non-profit organization advocating for sex

65. An article in Le Journal des Entreprises anticipated difficulties with the 2016 deadline. There is uncertainty about how widely the quota will apply: the target goals are aimed at companies with greater than 500 employees and greater than 50 million euros in sales, but some of these companies only have an executive committee and not a board of administrators. In addition, for companies located outside of Paris, the supply of potential female administrators is more limited. Marianne Peyri, Parité. Des Avancées Laborieuses [Parity. Laborious Progress], LE JOURNAL DES ENTREPRISES (2014), available at http://www.lejournaldesentreprises.com/ national/actualite/infrastructures/parite-des-avancees-laborieuses-06-06-2014-225718.php, archived at http://perma.cc/YB84-B8YL.

66. Cross-ownership refers to corporate directors who serve on multiple corporations' executive committee or corporate board reflecting conjoined ownership stakes. Jay Dahya et al., Dominant Shareholders, Corporate Boards and Corporate Value: A Cross-Country Analysis, 87 J. FIN. ECON. 73 (2008).

67. Indeed, the business case literature proved relevant for the legislators who brought the law to the National Assembly. Jean-Francois Copé and Marie-Jo Zimmerman, both consistently referenced the potential improvement in corporate governance that would flow from the FCBQ. Jean-François Copé referenced the business case: "In ten years, the wealth of Europe will be its human capital. We need women and a real feminine leadership. Also, the link between the presence of women on boards and the performance of businesses is demonstrated by several studies." Interview by Au Feminin TV with Jean-François Copé, Avancez avec Les Femmes, (2011). Zimmermann presented a report to the National Assembly advocating parity that referenced the business case. MARIE-JO ZIMMERMAN, Rapport d'Information Fait Au Nom de la Délégation aux Droits des Femmes et a l'Égalite des Chances Entre les Hommes et les Femmes [Information Report on Behalf of Women's Rights Delegation and Equal Opportunities for Men and Women] (2011). Zimmermann also referenced the Gresy Report that advocated for the quota. BRIGITTE GRESY, Rapport Préparatoire a la Concertation avec les Partenaires Sociaux sur l'Égalité Professionelle Entre les Femmes et les Hommes [Preparatory Report for Agreement with Social Partners on Professional Equality between Women and Men] (2009).

68. Interview by Au Feminin TV with Jean-François Copé, Avancez avec Les Femmes, (2011); ZIMMERMAN, supra note 67; GRESY, supra note 67. 
inclusion, documented a positive correlation between the level of sex diversity on a firm's board and the firm's returns on investment and equity. ${ }^{69}$ Other studies have linked sex diversity to higher stock prices, though as with all such studies, the researchers acknowledge that they are documenting only correlation and not causation. ${ }^{70}$ Finally, a range of empirical analysis of the Norway quota has linked sex diversity to economic growth, though Norwegian researchers had found it difficult to control for the effects of the 2008 economic crash. ${ }^{71}$ French

69. Catalyst compared over 500 leading United States firms between 2001 and 2004 and found a positive correlation between board diversity and performance. Catalyst concluded that firms with the greatest proportion of women board members showed significantly higher returns on investment ("ROI"), return on equity ("ROE"), and return on invested capital than those with the smallest proportion. CATALYST, 2007 CENSUS: BOARD DiRECTORS 1 (2007), available at http://www.catalyst.org/knowledge/2007-catalyst-census-women-board-directors-fortune-500, archived at http://perma.cc/UX7K-XYF3. A similar study by Erhardt et al. came to a slightly different conclusion. This study, which examined 112 leading firms over five years, found a positive relationship between board diversity (gender, race, ethnicity) and both ROI and ROE, but suggested that performance might be inducing diversity rather than vice versa. Niclas L. Erhardt et al., Board of Director Diversity and Firm Financial Performance, 11 CORP. GOVERNANCE 102, 102-03, 109 (2003).

70. Another study conducted by Virtcom Consulting revealed that, over a five year period, the stocks of companies with significant board diversity outperformed both the Dow Jones Industrial Average and the NASDAQ 100, though they did not outperform the Standard \& Poor's 500 (“S\&P 500”). VirTCOM CONSUlting, BOARD DiverSificATION STRATEGY: REALIZING COMPETITIVE AdVANTAgE AND SHAREHOLder VAlue 4-5 (2009). Another study looking at the effects of corporate workforce diversity on stock price showed that in research-intensive Fortune 1500 companies, adding women to the top management team increased stock price (Tobin's q) in the period 1992 to 2006. Christian L. Dezs \& David Gaddis Ross, “Girl Power": Female PARTicipation in Top MANAgEMENT AND Firm PERformance 1, 6-12 (2008). Likewise, in a study of sex and racial composition of Fortune 500 board committees between 1998 and 2002, researchers found positive effects of diversity on ROI. See David A. Carter et al., The Gender and Ethnic Diversity of US Boards and Board Committees and Firm Financial Performance, 18 CORP. GOVERNANCE 396, 410-11 (2010).

71. Kenneth Ahern \& Amy Dittmar, The Changing of the Boards: The Impact on Firm Valuation of Mandated Female Board Representation, 127 Q. J. ECON. 137, 168 (2012) (finding that stock prices and Tobin's Q dropped after the imposition of the quota); Renée B. Adams \& Daniel Ferreira, Women in the Boardroom and Their Impact on Governance and Performance, 94 J. FIN. ECON. 291 (2009) (finding women have better attendance records on boards than men, men on diverse boards have better attendance records than men on homogeneous boards, and diverse boards will focus more on monitoring); Benjamin E. Hermalin \& Michael S. Weisbach, Boards of Directors as an Endogenously Determined Institution: A Survey of the Economic Literature, 9 ECON. POL'Y REV. 7, 12 (2003) (reviewing literature on board composition and concluding there is little evidence to suggest a relationship between composition and firm performance and a negative correlative relationship between board size and firm performance); Benjamin E. Hermalin \& Michael S. Weisbach, Endogenously Chosen Boards of Directors and Their Monitoring of the CEO, 88 AM. ECON. REV. 96 (1998) (examining bargaining between the CEO and board of 
proponents of the quota cited to these studies in the campaign to adopt a mandatory requirement.

Corporate and management consultant studies also contribute to the literature linking sex and performance. McKinsey's study, "Women Matter," has argued since 2007 that firms that included women in management performed better. ${ }^{72}$ Likewise, a 2012 study by Credit Suisse confirms a correlation between share price and return on equity performance and the inclusion of at least one woman on the board. ${ }^{73}$ The Credit Suisse study cites several factors that women's inclusion may signal, including better effort across the board, better mix of leadership skills, access to a wider pool of talent, a better reflection of consumers, improved corporate governance, and greater risk aversion. ${ }^{74}$ On this last point, the study links higher proportions of women to lower levels of debt, a factor also linked to share price performance. ${ }^{75}$

It is important to note here that the existing empirical literature does not uniformly support a positive association between sex diversity and improved corporate performance. A significant body of research find an empirical link between gender diversity and negative outcomes. Of particular note is post-quota research linking the quota in Norway to diminished corporate performance. Research on Norwegian firm valuations from business economists Ahern and Dittmar in the wake of the Norwegian quota showed that firm valuations dipped, in large part because the quota compelled firms to hire younger and less experienced female board members. ${ }^{76}$ Similarly, economists Matsa and Miller's work suggests that Norwegian boards affected by the quota reduced their workforces less than comparable firms, increasing labor costs and reducing shortterm profits. ${ }^{77}$

In addition, as noted earlier, most studies caution that arguments for causation are suggestive rather than conclusive. More generally, empirical work faces great difficulty in establishing a definitive link between a demographic trait like sex and performance: performance is affected by such a multitude of factors, notably the variation of board-executive relations, and controlling for them all

directors and how boards are able to monitor the CEO); KNUT NYGAARD, FORCED BOARD CHANGES: EVIDENCE FROM NORWAY (2011) (after the quota was emplaced, firms with lower information asymmetry between insiders and outsiders experience positive cumulative abnormal returns, while firms with high information asymmetry experienced negative cumulative abnormal returns that were insignificant).

72. Women Matter, MCKINSEY \& COMPANY, www.mckinsey.com/features/women_matter (last visited Aug. 9, 2014), archived at http://perma.cc/XD8Z-JDLV.

73. Credit Suisse, Gender Diversity and Corporate Performance (2012).

74. Id.

75. Id.

76. Ahern \& Dittmar, supra note 71 , at 167.

77. Matsa \& Miller, supra note 5. In line with Matsa and Miller's study, Magnier and Rosenblum have suggested that adding women to corporate boards will make boards more prostakeholder. See Magnier \& Rosenblum, supra note 28. 
might well be impossible. ${ }^{78}$

\section{B. Theoretical Explanations for the Sex-Performance Link}

Beyond empirical work, corporate governance theorists have identified a range of institutional mechanisms that might help to explain how sex diversity could translate into improved corporate performance. One such mechanism is the presence of the role models for women workers. ${ }^{79}$ In recent work drawing on fifteen years of data from 1500 S\&P firms, organizational management scholars Dezso and Ross have argued that having women in top management motivates females in middle management to perform and sharpens managerial performance in firms focused on innovation. ${ }^{80}$ Having women at the top may encourage other women to advance in the corporate hierarchy. ${ }^{81}$

In the same vein, scholar Lisa Fairfax has proffered other mechanisms through which sex and ethnic diversity in the boardroom might enhance a corporation's bottom line. ${ }^{82}$ First, board diversity might make the corporation more sensitive to the interests of consumers and employees, both groups that are increasingly diverse. ${ }^{83}$ With regard to sex in particular, she asserts that corporations with female leaders tend to favor flexible work hours and family life policies. ${ }^{84}$ Diverse boards can help to reduce other costs that accompany a nondiverse board: diversification improves corporate image, ${ }^{85}$ reduces social and

78. Andrew Pettigrew, On Studying Managerial Elites, 13 StRAT. MAN. J. 163, 170 (1992).

79. CRISTIAN DEZso \& DAVID Gaddis Ross, Female REPRESENTATION IN TOP Management. Improve Firm Performance? A PANel Data InVESTigation 1, 3 (2011).

80. Id.

81. Id.

82. Lisa Fairfax, Women and the "New" Corporate Governance, Clogs in the Pipeline: The Mixed Data on Women Directors and Continued Barriers to their Advancement, 65 MD. L. REV. 579, 602-05 (2006).

83. Lynne L. Dallas, The New Managerialism and Diversity on Corporate Boards of Directors, 76 TUL. L. REV. 1363, 1384-85 (2002).

84. Carolyn Kay Brancato \& D. Jeanne Patterson, Conference Bd., Board DiVERSITY IN U.S. CORPORATIONS: BEST PRACTICES FOR BROADENING THE PROFILE OF CORPORATE BOARDS 8 (1999). These tendencies toward more flexible policies should lead to increased employee and consumer satisfaction - fostering less employee turnover and minimizing the costs associated with turnover, as well as encouraging repeat customers. James K. Harter et al., BusinessUnit-Level Relationship Between Employee Satisfaction, Employee Engagement, and Business Outcomes: A Meta-Analysis, 87 J. APPLIED PsychOL. 268, 273-74 (2002).

85. A European Commission study validated this theory finding that diversity programs not only had a positive impact on employee motivation, but also noted an increase in customer satisfaction (fifty-seven percent) and an improvement in brand image (sixty-nine percent). European COMmission, THE COSTS AND BENEFITS OF Diversity (2003), available at $\mathrm{http} / / /$ ec.europa.eu/justice/gender-equality/files/gender_balance_decision_making/report_genderbalance_2012_en.pdf, archived at http://perma.cc/59S9-PJH9. 
economic costs of discrimination and harassment, ${ }^{86}$ and enables boards to identify broader market opportunities and tap wider market power ${ }^{87}$

Research indicates that women make a difference in large part by changing aspects of a group's process. ${ }^{88}$ For example, a study by organizational behaviorist Anita Woolley and her team has linked women's presence to different kinds of communication in a group setting. ${ }^{89}$ They argue that women are better at social perception, and are more able to take turns rather than dominating a team discussion, which in turn reduces the likelihood that a team will suffer from groupthink. ${ }^{90}$ Another study by Carnegie Mellon measured the "collective intelligence" of a small group of people and found that, all else being equal, teams with more women scored higher than teams with fewer women. ${ }^{91}$ Researchers concluded that increasing sex diversity enhanced the board's overall effectiveness by facilitating higher quality decisions through improved monitoring, mitigating groupthink, and boosting collective intelligence. ${ }^{92}$ More efficient teams were less often dominated by a few group members and were more open to diverse viewpoints. ${ }^{93}$

Research linking gender diversity with differences in process supports the link between gender and these process differences, particularly as those relate to corporate accountability. A 2001 study by the Conference Board of Canada linked gender diversity on boards to a range of accountability practices. According to the board's internal research, ninety-four percent of firms with three or more women monitored the implementation of corporate strategy (vs. sixty-six percent of all-male firms); ninety-four percent of gender-diverse boards

86. Fairfax, supra note 82, at 579 (citing Steven A. Ramirez, Diversity and the Boardroom, 6 STAN. J. L. BUS. \& Fin. 85, 108-09 (2000)).

87. Id. at 579 (citing Marleen A. O'Connor, The Enron Board: The Perils of Groupthink, 71 U. CIN. L. REV. 1233, 1308 (2003)). Marleen O'Connor termed it “market reciprocity," how a diverse board responded to broader groups. O'Connor, supra at 1308. Fairfax provides the poignant example of Jill Kerr Conway, the first woman director at Nike. Conway encouraged her fellow board members to begin marketing to women, a strategy that has proved extremely profitable as the newly targeted market has reciprocated into a significant portion of Nike's business. See also Carol Hymowitz, In the U.S., What Will It Take to Create Diverse Boardrooms?, WALL ST. J., July 9, 2003, at B1.

88. Some studies show that female board members have higher attendance at meetings and women are more open to joining monitoring committees. Adams \& Ferreira, supra note 71, at 308. This study linked improved attendance and monitoring to stock price increases. See also DEZSO \& Ross, supra note 79, at 6-12 (suggesting that women may bring particular strengths to research intensive industries, thus the "female participation effect should be particularly significant when collaboration and creativity are especially important").

89. Anita Williams Woolley et al., Evidence for a Collective Intelligence Factor in the Performance of Human Groups, 330 SCIENCE EXPRESS 686, 688 (Sept. 30, 2010).

90. Id.

91. Id.

92. Id.

93. Id. 
ensure the enactment of conflict-of-interest guidelines (vs. sixty-eighty percent); and firms with women on their boards were more likely to use committees and in particular an executive committee to assist corporate decision-making. ${ }^{94}$

More generally, research has suggested that sex diversity matters because women bring with them different approaches to decision-making, offering fresh descriptive categories, and novel decision-making frameworks, heuristics, and classification systems. ${ }^{95}$ Political scientist Scott Page has reviewed a wide range of empirical studies on the connection between diversity on a number of traits and performance. ${ }^{96}$ Page focuses on the way in which different groups of people offer maps of reality that differ in terms of their categories, frameworks, heuristics, and classification systems. ${ }^{97}$ For example, biologists see the world differently than physicists, because they organize information according to different frameworks, categories, and classifications. ${ }^{98}$

Importantly, Page notes that diversity matters in some instances and not in others: diverse approaches are useful when groups are engaged in innovative tasks and experience little difficulty in communication, but are less useful when groups are engaged in routine and repetitive tasks requiring little innovation or problem solving. ${ }^{99}$ In sum, Page suggests that sex matters because it brings in diversity on other axes that are associated with sex. ${ }^{100}$

Whether diversity matters because of communication or decision-making frameworks, the relative number of women on a corporate board is likely to affect whether sex diversity is linked to differences in performance. ${ }^{101}$ Business sociologist Rosabeth Moss Kanter identifies the key threshold that constitutes a critical mass as thirty-five percent. ${ }^{102}$ Below this threshold, the majority can simply ignore a minority's presence; above the threshold, women can exert sufficient influence to change the group's decision-making in meaningful

94. Vanessa Anastasopoulos et al., Women on Boards: Not Just the Right Thing, But the Bright Thing, The CONFERENCE BoArd OF CANADA, 5-6 (2002), available at http://www. conferenceboard.ca/e-library/abstract.aspx?did=374, archived at http://perma.cc/LN89-BZB3.

95. Adams \& Ferreira, supra note 7, at 324-25.

96. Scott E. Page, The Difference: How the Power of Diversity Creates Better GROUPS, FIRMS, SCHOOLS, AND SOCIETIES 314 (2007).

97. Id.

98. Id. at $30-48$.

99. Id. at 323-26.

100. Id.

101. Rosabeth Moss Kanter, Some Effects of Proportions on Group Life: Skewed Sex Ratios and Responses to Token Women, 82 AM. J. SoC. 965, 966, 988 (1977). Kanter argued that only structural change in organizations might achieve real shifts in the allocation of power, and these structural changes would in turn change people as individuals, while changing the mere identity of individuals would not alter the corporation overall.

102. Id. at 988. This idea of critical mass motivated corporate board quota ("CBQ") advocates in Norway to push for a forty percent threshold for the "minority" sex. Sex minorities will be excluded from decisions unless they attain a "critical mass" - in sufficient numbers, minorities are in a position to demand that the organization include their opinions. See DHIR, supra note 3. 
ways. ${ }^{103}$ A more recent study argues that when three or more women are present on a board, women no longer represent "women" but are instead seen as individuals, and that at that point their collaborative style might begin to "influence the content and process of board discussions more substantially."104

At the same time, determining the precise threshold of diversity that constitutes critical mass will depend on the way in which sex matters. For example, if diversity improves stock price because women are more risk averse, then the level of diversity that would constitute critical mass will depend on the dynamics of decision-making with regard to risk. ${ }^{105}$ In contrast, if sex diversity improves performance because quotas tap into a new pool of talent, the threshold for critical mass might be lower. ${ }^{106}$

\section{DATA AND METHOD}

Our analysis draws upon interview data collected in connection with the study. Between October of 2011 and February of 2012, we organized thirty-one interviews with CAC-40 board members and thirty-six individual interviews of subjects who had knowledge about corporate board decision-making in France. Twenty-three of the interviews were with current and former members of corporate boards from CAC-40 French firms. The remainder consisted of seven

103. Earlier work establishes the limited effect of token representation. See Devon W. Carbado \& Mitu Gulati, Race to the Top of the Corporate Ladder: What Minorities Do When They Get There, 61 WASH. \& LEE L. REV. 1645, 1689-90 (2004); Lani Guinier, The Triumph of Tokenism: The Voting Rights Act and the Theory of Black Electoral Success, 89 MicH. L. REV. 1077 (1991).

104. Vicki W. Kramer et al., Executive Summary, Critical Mass on Corporate Boards: Why Three or More Women Enhance Governance, 11 WELLESLEY CTRS. FOR WOMEN REP. 3 (2006) [hereinafter Kramer et al., Critical Mass on Corporate Boards].

105. See Michel Ferrary, When Gender Diversity Protects Stock Prices From the Crash, CERAM Business SCHOOL (2009); Michel Ferrary, Why Women Managers Thrive in a Down Turn, FinANCIAL TIMES (March 2009), http://www.ft.com/cms/s/0/27836d74-04e4-11de-8166000077b07658,dwp_uuid=1d22aad4-0732-11de-9294-000077b07658.html, archived at http://perma.cc/KUZ9-JV2N. Michel Ferrary (CERAM Business School, France) found a direct correlation between the proportion of women in top management at a corporation and its stock price during a time of general economic downturn. He found that, "the more women there were in a company's management, the less the share price fell in 2008." Ferrary suggests that women managers tend to avoid risk and focus more on a long term perspectives, balancing the risk-taking style of their male colleagues, a trait especially important in protecting profits in bad times.

106. Ronald Burke, Women on Canadian Corporate Boards of Directors: Still a Long Way to Go, WoMEn ON CORPORATE BOARDS OF Directors 97 (2000). According to Burke, there are not currently enough talented male directors to fill open spots. CEOs are rejecting invitations to join boards at increasing rates and men currently serving on boards do not have the time to take on additional responsibilities. This makes the continued reliance on male CEOs for board members less practical and potentially dilutes quality. Accordingly, firms must expand their searches beyond the traditional talent pools. 
interviews of industry experts, academics, and the principal sponsor of the statute. ${ }^{107}$ Aggregate characteristics of the board member interviewees are shown in Table 1.

Table 1. Demographic Data N=24

\begin{tabular}{|c|c|c|}
\hline & $\underline{\mathbf{n}}$ & $\underline{\text { n female }}$ \\
\hline \multicolumn{3}{|l|}{ Gender } \\
\hline Male & 11 & \\
\hline Female & 13 & \\
\hline \multicolumn{3}{|l|}{ Seniority } \\
\hline Junior (under 55) & 4 & 3 \\
\hline Mid-level (55-65) & 13 & 6 \\
\hline Senior $(65+)$ & 7 & 4 \\
\hline \multicolumn{3}{|l|}{ Multiple Boards } \\
\hline Yes & 7 & 6 \\
\hline No & 17 & 1 \\
\hline \multicolumn{3}{|l|}{ Industry } \\
\hline Consumer & 4 & 2 \\
\hline Finance & 4 & 3 \\
\hline Industrial & 10 & 5 \\
\hline Service/Telecom & 6 & 2 \\
\hline French & 22 & 11 \\
\hline Foreign & 2 & 2 \\
\hline
\end{tabular}

In recruiting participants for the interviews, we targeted members of CAC-40 firms, and recruited via sex-specific snowball sampling. ${ }^{108}$ The fact that the

107. A full transcript, a redacted transcript, and a translated redacted transcript are on file with the authors. As noted earlier, all interviews will be referred to by their identification number with an "M" or an "F" marking the sex of the interviewee, i.e., "Interview with 19F."

108. Participants were asked to recommend an additional male and female prospective 
sample was evenly divided between male and female does not reflect the stillpersistent sex imbalance found in the subject population; the oversample of the female population was deliberate to avoid the possibility that a representative sample would reflect a predominantly male account of board decision-making, a possibility quite salient to the results of the study.

In addition to corporate board members, we interviewed two French legislators, one of whom was the author of the bill proposing the sex quota. Other interviews included two search professionals, a coach, and five academics, whose input was useful to understanding and putting into context the board member interviews.

Nearly all interviews were conducted in French. Interviews were openended; the interviewer worked from a set of questions that served to guide the individual interviews. ${ }^{109}$ Most interviews lasted approximately one hour and mostly took place at the member's place of work. All but one of the interview sessions were audio-recorded with the consent of the participants, and all of the recordings were later transcribed and then, for most, translated from French to English. ${ }^{110}$ To protect anonymity of the board members and their firms, all references to individuals and their firms have been redacted and replaced by coded identification numbers in the following discussion.

We collected data on corporate board members' attitudes about sex and corporate board decision-making. Questions pertained to four distinct but related topics: the interviewee's board experience, the interviewee's opinion on the firm's compliance with the quota, and whether the quota would affect the functioning of the board with regard to process and with regard to substance.

More specifically, participants were asked a range of questions relating to the subjects' perceptions of the difference that sex diversity on the board had had on board meetings and corporate performance. To distinguish process from substance, questions asked participants to distinguish their experience of the interactions on the board (process) and the substantive decisions made by the board (substance). The temporality of the questions and answers varied: some responses were retrospective while others were prospective, and even those grounded in past experience necessarily faced limits because few of them had spent much time during the period in which no women were present on corporate boards. ${ }^{111}$

participant.

109. Preliminary research revealed that it would be impossible to acquire enough advance knowledge to fashion a set of uniform questions that would yield objective data disposed to a quantitative analysis prior to performing the interviews. Instead, we opted to use open-ended, qualitative study in order to enable participants to express the nuance of their opinions and experiences. See Anselm Strauss \& Juliet Corbin, Basics of Qualitative Research: Grounded THEORY PRocedures AND TECHNIQUes 23 (1990).

110. One subject refused. Extensive notes of this conversation were used in place of a transcript.

111. For example, as one female board member stated: "So I can see what is running today, I do not know what it was before. I cannot compare before and after. [In my current position] I just 
As much as possible, we have attempted to preserve the authentic voice, corporate norms, and colloquialism of the participants in the translation process. For example, we took care to preserve the distinction between diversity and mixité, or the mixing of sexes, which both refers to sex difference specifically and distinguishes sex difference from other kinds of diversity as a subject for legal remedy. The use of this distinct term reflects a central distinction drawn in the French context between the two concepts, even as diversity remains central in the United States.

We note at the outset that the method of interviewing corporate board members themselves to assess the link between sex and corporate performance necessarily has both strengths and some significant limitations. On the plus side, corporate board members' inside perspective on the functioning of firms means that they are more likely to understand both the big picture overview of corporate board function and the details of that function. The members themselves are more likely to understand day-to-day micro-details of decision-making and the dynamics of board meetings.

In this study, qualitative interviews were chosen in order to shed light on whether and what mechanisms connect the sex composition of a corporate board to the performance of the firm. ${ }^{12}$ In the same vein, qualitative interviews are well-suited to provide fertile ground to enable scholars to generate hypotheses for future work; as we discuss more fully in the conclusion, this project provides a number of testable hypotheses regarding the addition of women to a corporate board and firm performance. ${ }^{113}$

At the same time, and perhaps for the same reasons, the interview as primary method necessarily had significant limitations. As participants, board members may have been too close and too invested in a particular view of governance to have an objective perspective. More importantly, most board members may have been too limited in their capacity to identify links between sex and differences. Participants were likely limited in their capacity to even perceive sex differences, or to distinguish their presence in process or substantive decision-making, let alone to sort out whether sex matters in corporate performance-indeed, several resisted the idea outright. In addition, many board members have served only on mixed-sex boards and have no framework for comparison to detect sex differences.

More generally, the qualitative interview has limited reliability in terms of providing accurate descriptions of what happens in the corporate boardroom, relying in a second-order way on our interpretation and analysis of board members' interpretations of corporate board experience. ${ }^{114}$ To address this

arrived, I do not know how it was before." Interview with 15F.

112. Pettigrew, supra note 78 , at 171.

113. Erica Schoenberger, The Corporate Interview as a Research Method in Economic Geography, 43 PROFESSIONAL GEOGRAPHER 180, 181 (1991). This study also draws on research design based in Grounded Qualitative Theory. BARNEY G. GLASER \& ANSELM L. STRAUSS, THE Discovery of GROUNDED THEORY: STRATEGIES FOR QUALITATIVE RESEARCH (1967).

114. GLASER \& STRAUSS, supra note 113 , at 183. 
challenge, in addition to asking more open-ended questions, we prompted participants by asking them about potential sex differences on corporate boards identified by previous research. This technique helped to focus participants on potentially important differences that they may or may not have connected to sex, although members' limited ability to spot such differences might still constitute a significant limitation. ${ }^{115}$

Finally, this project faced comparative challenges. Legal and cultural gaps between the United States and France required us to attend carefully to a rigorous comparative method to understand the full nature of the comparison in corporate governance norms. ${ }^{116}$ Where appropriate, we have remarked on the presence of potential cultural differences and attempted to highlight those ways in which our results might not generalize to the United States or more broadly to other countries. At the same time, the opportunity to study French corporate boards represented a unique opportunity to investigate the impact of sex on corporate boards operating under the requirements of the quota.

\section{Results: Process And Substance}

Three themes dominated the participants' responses to interviewer questions: (i) Sex diversity affected the process of board decision-making because the presence of women changes group dynamics and communication; (ii) Sex diversity did not affect, so far as subjects could detect, the substantive decisions that the boards made, at least insofar as the focus of such diversity was the female-ness of newly added members; and (iii) To the extent that new members of the board had an impact on substantive outcomes, it appeared likely that this was less because they were women and more because they were outsiders who came from different countries, different schools, and with different areas of expertise.

\section{A. Effect of the Quota and Sex Diversity on Process}

\section{Differences in Quality of Participation.-Discussion with participants}

115. Schoenberger, supra note 113 , at 187.

116. Darren Rosenblum, Internalizing Gender: Why International Law Theory Should Adopt Comparative Methods, 45 COLUM. J. TRANSNAT'L L. 759, 776-84 (2007). A comparative study requires intense familiarity with and examination of local context as a means to arrive at a fuller understanding of the import and meaning of the law studied. A risk with all comparative work is that the study may better reflect the values of the observer rather than the observed. Teemu Ruskola, Legal Orientalism, 101 MicH. L. REV. 179, 190 (2002). To minimize this risk, this study's comparative methodology draws on careful contextual knowledge to ensure that appropriate care has been used in drawing conclusions and effecting translations across cultures. Comparative work poses several challenges, but it fits neatly with the grounded theory approach to qualitative studies in that both involve an awareness of the subjectivity of the scholar within the study itself. See generally Günther Frankenberg, Critical Comparisons: Re-thinking Comparative Law, 26 HARV. INT'L L.J. 411 (1985); Annelise Riles, Wigmore's Treasure Box: Comparative Law in the Era of Information, 40 HARV. INT'L L.J. 221, 222 (1999). 
made clear that they thought women's presence on boards had affected the process of decision-making, and in particular, the level of member participation and the quality of their reasoning. First, women appear to be more likely to raise new points, and to raise difficult subjects openly. ${ }^{117}$ Several board members stated that women reserved their comments for fresh perspectives, in contrast to men who were more likely to repeat points made earlier:

Women have a habit of censoring themselves - observe a group where there are only men and one or few women, and the men will always speak first. Always. And when the women speak it is to say something different. If they have to say the same thing, or something approximate, they stay quiet. ${ }^{118}$

Participants also noted a sex difference in the precision with which women posed questions or made comments (both in their point and in their manner). Participants reported that women board members were more "detail oriented,"119 or as others put it, more "methodical." Women appeared to the subjects to be more openly willing to raise concerns: board members reported that where men feared expressing their ignorance, the women voiced those doubts openly:

I think that women possibly have a tendency to dare to say what they don't understand and to pose questions while men possibly would be a bit scared of being perceived as the one who does not know and thus it's better to not ask and to be discreet when one does not understand. ${ }^{120}$

Women were also reported to be more likely to ask questions designed to elicit additional information. One of the subjects opined, "[T] to pose questions like: 'I'm not sure that I understand why they're proposing to do this' and often when there are questions like that, not necessarily posed by women, but in this circumstance women pose these questions more easily and finally there's someone who says 'Oh yeah, me neither. I don't understand and can you explain this." "121 Another female board member said: "I think it is more transparent and on the table. I mean, for women, there are no stupid questions we pose. It is much more honest, it is much less . . 'Ah, I will not say that because my neighbor will think ....",122

In line with previous research, these results suggest that women's presence on the board might force fuller explanations to surface, a general theme articulated by many of the board members. One board member articulated that the way men communicate without women present is by using "shortcuts," or communicating without saying everything. ${ }^{123}$ In the participants' view, this loss

117. Interview with $12 \mathrm{~F}$.

118. Id.

119. Interview with $14 \mathrm{~F}$.

120. Interview with $4 \mathrm{~F}$.

121. Id.

122. Interview with $19 \mathrm{~F}$.

123. Interview with $13 \mathrm{~F}$. 
of the ability to speak in shorthand had the effect of pushing boards to articulate their reasoning more fully.

One woman participant, who had a great deal of board experience and was particularly reticent to articulate that a sex difference existed, said that she thought this manner of communication in which the "naïve" questions posed by women make the discussion explicit, forced the board to detail its reasoning. ${ }^{124}$ As another female board member said: "it happens that women ask hard questions more easily and finally there is someone who says 'ah yes, me neither, I don't understand so could you explain it to us?' Although if nobody asked this question in the first place, the subject would just go by without discussion." 125 Beyond the kind of questions asked, many participants asserted that women presented more "reasoned" arguments. ${ }^{126}$

At the same time, other participants expressed the opinion that women did not affect the process of board decision-making. Indeed, one board member said that women's presence did not make a difference at all. ${ }^{127}$

2. Differences in Confrontationalism.- Sex diversity also appears to have affected the tone of board interactions. One participant noted that after her first meeting - the first with a woman present - the men had said to her, "That was the best meeting we ever had. We fought about nothing and tried to discuss things calmly." " 28 French subjects were likely to frame this in terms of etiquette and civility:

That there are women on boards changes necessarily the situation compared to when there were not. Because men, from the instant they are in the presence of women, adopt civil behavior that are not what they use when they are among guys. ${ }^{129}$

Not only did women avoid combative posturing, but several participants also noted women's “civilizing" effect on male behavior in meetings. As one (male) board member said, "Because men, once they're in the presence of women, adopt a civil behavior that is not what they allow themselves when they are among men." 130 The fact that men behave differently around women may serve as the basis for several of the discussion-related differences that occur with the presence of women on the board of directors. ${ }^{131}$

Several participants (many of them women) noted that women were less territorial or power-driven in their participation. Although one female board member argued that women should not be perceived as having "hairdresser

124. Interview with $7 \mathrm{~F}$.

125. Interview with $4 \mathrm{~F}$.

126. Interview with $21 \mathrm{~F}$.

127. Interview with $18 \mathrm{~F}$.

128. Interview with $3 \mathrm{~F}$.

129. Interview with $5 \mathrm{M}$.

130. Id.

131. Although one male board member implied that men did not behave differently when women were around. Interview with $22 \mathrm{M}$. 
conversations," at the same time, women were perhaps "more sociable," and they "do not live a conversation as a power play." 132 Other female board members said that men's comments tended to be more "territorial," occurring between "males in a dominant position: 'I mark my territory and don't [you] touch my turf." "133

In discussing women's influence, participants pointed out the role of French custom with regard to etiquette between the sexes. Thus, one female board member noted that owing to "French gallantry, if two people raise their hands and it happens one is a man and the other a woman, the man will systematically propose that it be the woman who speaks first." 134 Another (male) participant attributed the same fact to the custom that newer members are invited to speak first, and since the women tend to be more recent arrivals, they speak first. ${ }^{135}$

As this last set of comments demonstrates, often participants agreed on observations, but disagreed on whether the source was a woman's female nature or some other aspect of her participation. For example, one female board member used stereotypical language in arguing that women employ a softer and more "feminine" tone, especially about "disagreeable" things, or "bothersome" issues:

So because we [women] do not say the same things and in particular disagreeable things with the same tone. We say it more softly with more femininity ... I find, as long as one stays a woman. I'm not saying that you have to have skirts up to one's ass. But staying feminine, staying oneself, I consider it a goal, because we're in a world of men, and that, it's worth saying, it is not the same thing. ${ }^{136}$

In sum, with regard to process, important changes were credited to women's presence, including some more methodical, even reasoned deliberation, with fewer "shortcuts," less conflict, and more civil behavior during the process of board deliberation.

\section{B. Effects of Sex Diversity on Substantive Decision-making}

Beyond process, interviewees also were asked whether the board's substantive decisions had shifted as a result of women's presence. As a general matter, when asked whether sex diversity affected voting by the board of directors, many resisted the premise of the question, opining that sex could not make a substantive difference. When pressed on particular topics, like whether women were more likely to oppose workforce reductions, most members answered in the negative (though as discussed below, one female board member noted that in a recent board vote on executive pay, the only negative votes on her

132. Interview with $19 \mathrm{~F}$.

133. Id.

134. Interview with $15 \mathrm{~F}$.

135. Id.

136. Interview with $3 \mathrm{~F}$. 
board were cast by two women). ${ }^{137}$

1. Participant Resistance.-Getting participants to focus on the question of substance was initially quite difficult; many participants rejected at the outset the notion that sex (as opposed to other traits or experiences) could make a dispositive difference in substantive choices by the board. One senior female board member said:

Here we are new members, but we do not feel we have a women's role to play more than an administrator role, or put in play our own personality and our own past experience. So me what I bring over other is industrial experience I gained in . . . , but others bring more management experience or financial experience, so this is where I stand out. $^{138}$

One male executive concurred: "I have the tendency to think it's because above all they (board members) have excellent personal skills whether they are men or women. And if they ask good questions it's because they are good with breasts or without breasts." 139 Put in less sexist terms, this male member suggested that what mattered were skills, not the sex of the board member.

One male board member represented the views of many men and women participants alike, saying that he found the idea completely "absurd:"

Are they more rigorous? I know many women who are rigorous and others who are less so, as with men. One is rigorous or not. The division isn't about whether one is a man or a woman. It's absurd to say that it will change something. As if we were as different as the moon and the sun. We are happily much closer than different. ${ }^{140}$

Some members raised the possibility that women members had adopted distinctively masculine characteristics (a strategy discussed in the literature on women's strategic efforts to fit into male environments). For example, one male member said pointedly, "They were more guys than the guys." 141 Another male board member said the following:

And that in the careers which are those of men above all-please do not hold this against me what I am going to say because I am almost ashamed even before saying it - but the ladies who succeed frequently in the top jobs at the beginning are ... actually I have two under whom I have worked, they were, I think I can say this, they were more guys than the guys. To say that they brought diversity is a vision, a view of the spirit. It is biologically [true] but it is true only biologically. ${ }^{142}$

137. Interview with $4 \mathrm{~F}$.

138. Interview with $7 \mathrm{~F}$.

139. Interview with $6 \mathrm{M}$.

140. Interview with $11 \mathrm{M}$.

141. Interview with $1 \mathrm{M}$.

142. Id. 
Members' resistance to the potential effect of sex on substance was all the more striking in light of consensus that women's presence did affect the decisionmaking process. Implicitly, the subjects seemed to believe that differences in process did not produce differences in the substantive outcomes of such process. One possible explanation for this dichotomy is that members see substantive decisions as relatively predetermined. In France, board members defer heavily to executive strategy, usually to approve it. ${ }^{143}$ Given this deference, which some scholars report is more acute in the French context, members might find it unlikely that sex (or any other factor for that matter) affects corporate board decision-making. ${ }^{144}$

2. Offering Participants Alternative Substantive Scenarios.-To prompt subjects to think about the kinds of substantive differences found in previous research, some participants were asked whether boards with women were more likely to differ substantively with regard to those particular traits or subjects - like labor and workforce reduction, risk aversion, or an increased stakeholder focus. ${ }^{145}$ In general, participants were reluctant to agree with these ideas. As one female board member said:

There's a sort of socialization in the societal sense of the members of the board that makes us that one is interested in subcontractors, one is interested in workers, one is interested in corporate social responsibility, one is interested, obviously in the environment ... this all concerns a bit everyone on the board. To different degrees: I am sure that those who come from banking or finance are more interested in cash flow and operational margin and less in this [social issues]. Coming back to the diversity of boards, so to say that women are more like this, I'm a little reticent to the extent that I see [a high level female executive on the board] react. She is less sensitive than I am on these issues. ${ }^{146}$

\section{More Risk Averse Outcomes}

In the earliest public discussions around the quota's adoption, the idea that women were more risk averse played an important role. Following the debate and earlier research, ${ }^{147}$ participants were asked whether they observed women

143. Id.

144. Fanto, supra note 8, at 53 n.108 (citations omitted) (In France, “[g]eneral research on boards of directors suggests that the director's background, as well as other social factors, such as group behavior and loyalty, conspire to ensure that boards are deferential to management and passive in protecting shareholder rights ... . The French situation is more acute since chief executives in large French companies have almost dictatorial powers.").

145. See, e.g., Matsa \& Miller, supra note 5, at 137 n.5; CREDIT SUISSE, supra note 73; Kent Greenfield, Defining Stakeholder Governance, 58 CASE W. RES. L. REV. 1043 (2008); Kent Greenfield, Reclaiming Corporate Law in a New Gilded Age, 2 HARV. L. \& POL'Y REV. 1 (2008).

146. Interview with $12 \mathrm{~F}$.

147. See FERRARY, supra note 105. 
members or boards with women making more risk-averse decisions or playing a role on audit committees.

Subjects were mostly resistant to the idea. ${ }^{148}$ One male board member admitted that women might be more risk-averse, but that this difference did not have much impact "because management elaborates the strategy." 149 A few participants opined that sex in fact played some role in risk aversion, but argued that women were more insistent on accurate measurement of risk, rather than more risk averse.

One female participant stated the idea this way: "[W]e will take risks if we have carefully measured them if we're in agreement on the fundamentals ... but it's not a refusal of risks, it is a different manner of analyzing that we do not lose reality. For me that is more the feminine attitude." 150

Likewise, another member promoted the view that women's orientation toward detail might lead to a more accurate appreciation of risk:

Compared to risks taken, no, I have not felt a different attitude between men and women. Actually, again, to have more precise elements that allow a real clarification of the decision, women put more in than men. So it's to know well how to measure and appreciate risk in a more probing way, yes. ${ }^{151}$

Both of these comments (and several more like it) reflect the idea that women are not "risk-averse" per se, but that deliberate consideration (perhaps motivated by lack of experience) might lead to a more accurate assessment of risk.

\section{More Policies Favoring Corporate Social Responsibility and Affirmative Action for Women}

In line with earlier research, some participants also discussed whether women board members had persuaded corporate boards to adopt family-friendly policies. ${ }^{152}$ Board members responded that although women might be inclined to adopt more family-friendly policies, this was not because they were women, but because they tended to be younger and thus more likely to have younger children. ${ }^{153}$ Likewise, this skepticism with regard to specific social issues surfaced elsewhere, with regard to firms that paid more attention to "working life." 154

148. Interview with $21 \mathrm{~F}$.

149. Interview with $22 \mathrm{M}$.

150. Interview with $19 \mathrm{~F}$.

151. Interview with 7F.

152. See BRANCATO \& PATTERSON, supra note 84 .

153. Interview with $17 \mathrm{~F}$.

154. Interview with $13 \mathrm{~F}$ ("[It gives] a good image of the company. It is therefore better to have more social services, social contributions within the company. It's better than not having. It does not depend on the weight of women on the board, and then it goes in the right direction. If this is easy, as part of working life for women, it will be easier for men too. There, also for people 
Participants did acknowledge differences with regard to women members' attitudes towards corporate social responsibility:

$[\mathrm{I}] \mathrm{t}$ is important that the company in its business model asks the question of its social responsibility and therefore requires that the board takes this dimension and does not only leave it to the management. And the presence of women, including more diverse board members should allow the board to disconnect from solely financial criteria to go to the extrafinancial which has for the company a strong impact and which is important for its performance. ${ }^{155}$

Another participant opined that women "would probably be more attentive to any sort of corporate social responsibility issues," although increased corporate social responsibility is also a trend more generally. ${ }^{156}$

At least one participant suggested that women board members influenced board substantive decisions that promoted women to positions of power and responsibility:

[W] hat is important is that women who are on the board promote women's access to positions of responsibility within the company. So in fact, women on the board in their role, apart from being a director like everyone else, it may be particularly likely to ensure that the company enables women to take leadership positions. So I do think that there is this desire, women who are on the board today, are particularly ensuring more women in positions of responsibility in the company. ${ }^{157}$

\section{E. Process and Substance: Stakeholder Perspectives}

Consistent with the earlier research from Norway suggesting that boards with more women are more reluctant to engage in workforce reduction, ${ }^{158}$ participants were asked whether boards with more women were more likely to consider the interests of labor or other stakeholders.

Some interviewees were receptive to the idea that women might be more sensitive to stakeholder interests, ${ }^{159}$ that "women will be more careful about what they will not actually see themselves. They will try to imagine what the

with disabilities so if you have a favorable business to accept inclusion. But in fact there are two things, we do it because we share this value or because we want to give a good image .... Or both can be together in parallel. But I do not see that it is because we have more women in the CA that goes in this direction. That I do not know, I cannot .... But I know that the staff is happy when there are women on the board. That is good.").

155. Interview with $17 \mathrm{~F}$.

156. Interview with $29 \mathrm{M}$.

157. Interview with $17 \mathrm{~F}$.

158. Matsa \& Miller, supra note 5, at 137 n.5.

159. Interview with $8 \mathrm{~F}$; see also Interview with $16 \mathrm{M}$. 
consequences might be for the stakeholders." ${ }^{160}$ In explaining this sensitivity, some members relied on stereotypes: one male board member commented that women would consider stakeholders more because they "have to take care of children." $" 161$

In contrast, other interviewees opined that women brought different stakeholders to the table because they were more likely to have had experience representing or working for such a stakeholder. One female board member stated:

What does resonate is that because of the diversity of experience that some women bring, because they bring a different experience because they're women, there's maybe more sense to do different stakeholders because they have experience of dealing with government, like in my case, or more experience in dealing with different types of organizations. If you know about how different parts of society work, you see more opportunities to respond to stakeholder concerns. ${ }^{162}$

When asked explicitly whether boards with more women would be less likely to fire workers, or whether workers would receive more favorable treatment in a post-quota France, board members expressed skepticism. One female board member was particularly hostile to the idea, stating: "Neither in my experience to date nor on the board have I seen that women are less likely to fire people-you know nobody is going to fire people for the fun of it."163

Another female board member acknowledged pro-labor decision-making by boards in general, but attributed it to French culture and not to the addition of women on boards:

In France you have large businesses, even if they fire people, they give them very important social advantages, very high unemployment benefits, we give them plenty of time to find a job, etc. We pay attention. Banks that have announced layoffs, they will do so abroad, but they will not do it in France because they know that France is so complicated .... I think it is rather the culture of the company and therefore the board is part of this culture, rather than the fact that women say "No, no, no, we should not fire people" and men say "Yes, yes, yes, we must fire them."164

In sum, board members were very reluctant to admit that sex qua sex had had any effect on corporate governance post-quota. Participants acknowledged that there were post-quota differences in risk aversion and sensitivity to stakeholders, but attributed these differences to other causes. The only substantive difference that members acknowledged had to do with women members' willingness to

160. Interview with $30 \mathrm{~F}$.

161. Interview with $28 \mathrm{M}$.

162. Interview with $30 \mathrm{~F}$.

163. Id.

164. Interview with $18 \mathrm{~F}$. 
adopt family or women-friendly policies. This combination of defensiveness on substance and concessions on stereotypically "feminine" policies raises the concern with reliability noted above; as insiders, board members may be too deeply invested to report objectively and lack the capacity to identify when sex actually makes a difference to corporate decision-making.

\section{THE QUOTA AS AN OPPORTUNITY TO RECRUIT OUTSIDERS}

In perhaps the most important insight drawn from the interviews, participants acknowledged that the quota might change the board's substantive decisionmaking, but not because the new members were women. Rather, members traced substantive differences to the fact that newly added women were outsiders with new and different perspectives: that is, newly added women were more likely to be junior, less likely to come from the Grandes Ecoles elite networks, more likely to be foreign, and more likely to have extensive experience in nontraditional areas like labor or the environment.

\section{A. General Value of Outsiders}

When asked about the real value of the quota, many members suggested that what was important was less the sex of the added members and more their newcomer status. As one male participant stated, "It is certain that the arrival of a new person on the board has an effect on the board, whether it is a man or a woman and this effect is more or less important according to the personality of the person in question." 165 A female board member said, "Afterwards, there was a great effect: having someone new. It's always something that makes the effect because suddenly we see with someone you do not know since forever who will always re-present new issues but I think it is true whether it is a man or a woman."166

When pressed to articulate why having new members affected the board, some board members suggested that independent decision-making (in contrast to the deference characteristic of French boards) was more likely with newcomers:

So with independent board members, there's their independence and so there's more change than to have a board member, I'd say, [of] current stereotype. And so someone who knows [Company X] for a long time, who is from the same background, or a woman from an international background who is much younger, for example, there you go, it would make more novelty. ${ }^{167}$

Interestingly, members acknowledged that bringing in outsiders created challenges for collective decision-making. One female board member participant argued that, particularly for smaller firms outside the CAC-40, adding new

165. Interview with $15 \mathrm{~F}$.

166. Interview with $4 \mathrm{~F}$.

167. Interview with $17 \mathrm{~F}$; see also Interview with $11 \mathrm{M}$. 
members might weaken the board: "If you take out half [the board] and put women in their place, well that's going to destroy the dynamic that was slowly going into place and as if the board served for something and then it serves for nothing." 168 She also noted that a weaker board would be less able to stand up to executive management. ${ }^{169}$

A few board member participants connected the outsider status of newly added female members to some of the process differences articulated elsewhere. In their view, because women were the newcomers, they were more "prepared" for meetings than men were, as well as "harder working." ${ }^{170}$ Said one participant, "[W]omen have the reputation of arriving with their materials well-prepared . . . to show they are up to it." ${ }^{171}$ Indeed, other members reframed the notion that there was a link between sex and risk aversion: one member suggested that riskaversion might be connected not to sex but to being new. ${ }^{172}$

\section{B. New Areas of Substantive Expertise}

Drawing on diversity research on the diversification of mental models and heuristics, participants discussed the general benefit of bringing in women with a broader range of experience than that possessed by the CEO-model of board recruitment. One female participant noted the horizon-broadening effect of the quota in this way:

[A]s there is no woman who is now president or CEO of CAC-40 companies, by definition, it is necessary to widen the circle. It is by definition. Anyway, I think the same way that we force ourselves to expand the circle because now we have an obligation to put women on in the same way, it will break the habit of going to find someone among the eighty people I described or perhaps 120 . And that, when we have broken the habit to pick people like you at this time, we will look for other people including men who have much more original horizons, less business perhaps more research-oriented, etc. ${ }^{173}$

Members also appeared to recognize that change could be accelerated both in terms of who left the board as well as who was added. As one male board member said:

It is with the choice that they are going to make of who stays. The game is not in who they recruit in itself. Because if we will look for women who are conformist copies of the men we removed, we will have exactly the same team. We will replace defenders with younger defenders, but

168. Interview with $15 \mathrm{~F}$.

169. Id.

170. Interview with $20 \mathrm{~F}$.

171. Interview with $21 \mathrm{~F}$.

172. Interview with $15 \mathrm{~F}$.

173. Interview with $19 \mathrm{~F}$. 
still defenders, that changes nothing. ${ }^{174}$

This member went on to say that the choices before the board included expanding the board's profile by including a foreigner, "or someone with a sociological sensibility, or an eminent ecologist." 175

Members suggested in particular that boards explicitly recognized the value of non-traditional substantive expertise. Many members suggested that firms have used a "two birds with one stone" kind of opportunistic reasoning. For example, a union representative on one board observed that when boards were looking for women to comply with the quota, they used the opportunity to find particular substantive expertise: ${ }^{176}$

Intellectually and professionally, in competence and even in terms of their preoccupations, I don't see any reasons except if when we search for women [board members] we search for women with particular interests [such as the environment], and then we would skew the statistics and say, you see, women brought this environmental perspective. ${ }^{177}$

\section{Outside the Grandes Ecoles Networks}

Consistent with Page's arguments about mental models, participants routinely noted the likelihood that newly added members would come from outside the Grandes Ecoles networks. Participants noted that in France's highly traditional corporate culture, a caste of bourgeois men exercise control over a "Franco-Français" network of cross-managed firms that involves mutual stake holding and/or board representation by leading firms in each other. ${ }^{178}$ According to the members, a Grandes Ecoles network, particularly the Ecole Polytechnique, predominates among the men running these firms. As these boards select new members, the alumnae of the Grandes Ecoles have traditionally been the most sought-after potential members of boards, in part because they share the same worldview and approach as the men who currently serve on the board. ${ }^{179}$

As one female board member stated, the sheer number of the women needed

174. Interview with $5 \mathrm{M}$.

175. Id.

176. French law requires some worker representation on large firm boards. AFEP \& MEDEF, $5^{\text {Éme }}$ RAPPORT ANNUEl SUR LE CODE AFEP-MEDEF DE 2013 [5th Annual Report on the AFEPMEDEF, 2013] (Oct. 2013), available at http://www.afep.com/uploads/medias/documents/5e rapport_application_du_Code_de_gouvernement_entreprise_Afep_Medef_Octobre_2013.pdf, archived at $\mathrm{http}: / /$ perma.cc/A974-EXFQ.

177. Interview with $5 \mathrm{M}$.

178. Interview with $19 \mathrm{~F}$.

179. François-Xavier Dudouet and Hervé Joly, Les Dirigeants Français du CAC 40: Entre Élitisme Scolaire et Passage par l'État [The Leaders of the French CAC 40: Between Academic Elitism and Run by the State], 2(21) SOCIOLOGIES PRATIQUES 35-47 (2010); see also Interview with $13 \mathrm{~F}$. 
to fill the board slots will force the boards to get out of the very limited Grandes Ecoles pool. ${ }^{180}$ Another female board member put it: "the stock of people is quite limited if compared with the stock of male persons." 181 Accordingly, board members noted that "by the sole game of numbers, by the number of women that must be found for the board terms, we will even so leave a bit the beaten path, énarques, etc." "182

Recruiters confirmed the occurrence of this post-quota opportunistic recruiting outside the social and professional networks of existing members:

So that means that to look for these women, one must look in pools that are not the habitual pools. There you have it, so that means that they will not be from the Grandes Ecoles, but that they will not have had great leadership posts and they will have still some progression to make, which does not mean that they will not have the skills to sit on a board, but it will break, I think effectively, some modes of cooptation and nothing but the fact that they have not be coopted in the same manner as the men on boards, that will create another form of expression. ${ }^{183}$

Indeed, studies regarding the profile of female directors in France at the time of the quota's adoption show that female directors are generally younger than their male colleagues ( 54.7 years old on average compared to 60.7 for men) and more likely to have international origins. ${ }^{184}$ Although this profile is shifting as many corporations take on new women directors, anecdotal evidence confirms this shift. ${ }^{185}$ Many new female directors hold degrees in law or business management in contrast to the more technical education received by their male counterparts. Male directors are most often graduates of the French Grandes Ecoles. Female directors also do not have the same experience at the top executive levels as male directors. ${ }^{186}$ The feminization of boards of directors may correlate with some diversification of skills and points of view on how to run a business. ${ }^{187}$ As the next section notes, given the extraordinarily narrow band of French society that has occupied corporate board positions,

180. Interview with $19 \mathrm{~F}$.

181. Interview with $13 \mathrm{~F}$.

182. Interview with $19 \mathrm{~F}$.

183. Interview with $17 \mathrm{~F}$.

184. L'OBSERVATOIRE DE LA RESPONSABILITÉ SOCIÉTALE DES ENTREPRISES \& L'INSTITUT FrANÇAIS DES ADMINISTRATEURS, L'ACCÈS ET LA REPRÉSENTATIVITÉ DES FEMMES AUX ORGANES DE GOUVERNANCE D'ENTREPRISE (2009).

185. Valérie Lion, Conseils d'Administration: ces Femmes Qui Cumulent [Boards of Directors: Women Who Combine], L'EXPRESS, 74 n.16 (May 2012).

186. Adams \& Ferreira, supra note 71, at 294.

187. A counterargument may assert that less executive experience may not constitute useful diverse experience. Indeed, Amy Dittmar's work on the lower experience among women on boards in Norway after their adoption of a corporate board quota correlates this with lower returns on equity. See Ahern \& Dittmar, supra note 71. 
diversification may also bring global market knowledge. ${ }^{188}$

\section{Outside of France: Foreign Perspectives}

Many interviewees noted that firms turned to foreign women to fill the quota, in part because firms saw foreign women as more experienced (generally and with regard to international transactions) than their French counterparts. One male board member explained:

[A]s I said, the French reservoir or pool is quite poor and limited, as by the way French companies are more international, etc. So, it's evidence that there's a need, it's clear, it's very healthy to bring in profiles of nonFrench people, it enlarges the ... it's very simple, it enlarges the pool and it's true that there could be interesting profiles in other countries. ${ }^{189}$

All participants who were chairs of their boards referenced the likelihood that at least some of the new board members (all of whom obviously would be female) would come from abroad. ${ }^{190}$ One recruiter confirmed this, saying, "All the big bosses of the CAC-40 tell you, above all give me foreigners." "Many members viewed the possibility of hiring foreign women as an opportunity: several participants referenced this as d'une pierre deux coups, in English, killing two birds with one stone. ${ }^{192}$

In the members' view, two factors seemed to be driving this perception. First, for French firms with extensive foreign revenue (either established or in development), recruiting board members from these markets would potentially aid in globalizing these firms, reflecting the rapid globalization of capital markets and the extensive foreign investment in France. ${ }^{193}$ As one member put it:

When you're a group that operates internationally with strong growth in emerging countries, it seems quite normal to have a board member who knows these issues, who is capable to come to the board with information about those countries . . . in terms of risk analysis ... strategic directions, there you have it . . . It is for that reason that, given the phenomenon of current globalization, there would be more and more foreign board members on boards. ${ }^{194}$

188. Global perspectives are likely quite promising in terms of generating productive diversity of perspective, of the type discussed by Page. See generally PAGE, supra note 96.

189. Interview with $23 \mathrm{M}$.

190. Interview with $18 \mathrm{~F}$.

191. Interview with $9 \mathrm{~F}$.

192. Translated literally it would be "from one stone two blows."

193. Interview with $1 \mathrm{M}$. In fact, foreign investors own three-fourths of the CAC-40 companies' capital. Anne-Marie Rocco, Loi Zimmerman: Encore un Effort d'Imagination! [Zimmerman Law: Another Stretch of the Imagination!], FEMMES (May 17, 2013), http://femmes.blogs.challenges.fr/archive/2013/05/17/loi-zimmermann-encore-un-effort-dimagination.html, archived at http://perma.cc/5VPB-MKK2.

194. Interview with $17 \mathrm{~F}$. 
Second, participants pointed out that French corporations would prefer nonFrench executives to French women without executive experience. ${ }^{195}$ As one female board member stated:

When you speak to headhunters who work today on filling board positions for women, they say to you that all the companies have the same robot portrait, that is to say, a woman, preferably foreign - because that way you kill two birds with one stone: you put at once sex and foreign - who is "head of business unit," "chief executive," or "chairman." "196

In addition, participants suggested that foreign women are favored because they are able to escape the social hierarchy that places the Grandes Ecoles at the pinnacle. As one foreign female board member stated: "so if you are not from these Grandes Ecoles and you are French, it will be a bit biased [against you]. But for me I am a foreigner, so . . . I am free of this dichotomy: those who belong and those who do not." 197 The presence of foreign women does not undermine the French social hierarchy as the presence of non-elite French women would.

Empirical research in 2014 on the French quota by management scholars Allemand and Brullebaut confirms a preference for foreign women: in the 112 Parisian firms under study, administrators selected women for the quota who were more frequently foreigners, from outside the company and from a legal background, despite the fact that selection criteria did not specify any of these as requirements. ${ }^{198}$ Likewise, the Fédération des Femmes Administrateurs confirmed a stronger presence of foreign women on CAC-40 boards, although both French and foreign women had elite educational profiles. ${ }^{199}$

195. Interestingly, one recruiter with whom we met laid out which nationalities were more compatible with French boards.

196. Interview with $19 \mathrm{~F}$.

197. Interview with $13 \mathrm{~F}$.

198. Isabelle Allemand \& Bénédicte Brullebaut, Le Capital Humain des Femmes Récemment Nommées dans les Conseils d'Administration des Sociétés Françaises Cotées à Paris [Human Capital of Recently Appointed Women Within Listed Companies' Boards in Paris], 18(3) INTERNATIONAL MANAGEMENT 20-31 (2014). A newsletter published in 2014 by L'Association des Femmes Diplomees d'Expertise Compatable Administrateurs ("AFECA") stated that the diversity of women on boards is still low and the women who are selected are among top executives and finance profiles. The newsletter hypothesizes that internationalization could help leverage boards' efficiency because it would develop a strategy of growth on foreign markets, develop cultural diversity within the boards, help spread best governance practices from all over the world, and incentivize French women to apply to foreign boards. La Place des Administratrices au Sein des Sociétés Cotées Sur Euronext Paris au 30 Juin 2013 [The Role of Women Within Euronext Listed Companies' Boards as of June 30, 2013], Association des Femmes Diplômées d'Expertise Comptable Administrateurs ("AFECA"), at 1-6 (2014).

199. Karima Bouaiss \& Agnes Bricard, Les Femmes Administrateurs au Sein des Conseils 
Importantly, in the view of participants, the recruiting of foreign women brings with it a different cultural set of norms. As one member put it:

Personally I am totally reticent with this discourse that women do business differently from men. Of course everyone does things differently, because personalities are different, Americans do not do business like the French. People from one company do not do business like those from another. ${ }^{200}$

Members noted that boards recruiting foreign women had to think carefully about the potential language barrier. Several board members commented that their boards function exclusively in French. ${ }^{201}$ Non-fluent members require translation, which can both prove inadequate and cumbersome. ${ }^{202}$

Indeed, some board members suggested that non-French speaking women would wield less power because of the language barrier: as one male board member said, "[t]hey will be weaker, and the reason I gave is the same for men." 203 One participant, a female professional coach, went even further to suggest that firms deliberately courted foreign women purposely to limit their input:

It's also a way to keep the power and not be disturbed on strategic aspects where these international women do not necessarily have the expertise, the look, the knowledge related to the country. Indeed, I think it's a bit biased, so. It is clear that this is a way to meet the law but at the same time is a way to keep its small area without necessarily having women who will come to disturb the strategy . . ${ }^{204}$

Others mentioned that cultural differences or national tensions (including historic issues with Germany) might surface to prevent the integration of a foreign board member. ${ }^{205}$

Participants were sensitive to the possibility that foreign women would be treated as tokens, there to comply with the quota but not given real political power. One recruiter suggested that foreign women might not be sufficiently attentive to the question of developing political power:

I think there is a real issue and that is a problem for women is that they

d'Administration des Sociétés du SBF 120 en 2013 [Women directors on boards of companies in the SBF120 in 2013], Fédération des Femmes Administrateurs (2014).

200. Interview with $23 \mathrm{M}$.

201. 'On top of it, there's a linguistic question. The most widely spoken language is English. In French firms, there are not many where the most widely spoken language is English. You are obligated to translate everything in English and thus you have to have Francophone women." Interview with $11 \mathrm{M}$.

202. Interview with $19 \mathrm{~F}$.

203. Interview with $28 \mathrm{M}$.

204. Interview with $2 \mathrm{~F}$.

205. Interview with $9 \mathrm{~F}$. 
often do not pay enough attention to develop their political meaning. That's a lot of work being done with them at all levels and especially when they arrive at the executive level, if they are to be on the board, what is their network, what is their image, what is their reputation, what is their appointment, they know how to interact in a way political decision-making body. ${ }^{206}$

\section{E. More Junior Than the Old Boys' Club: Women and Seniority}

Given the perceived lack of depth in the French pool of experienced women, some members thought that recruiting would be more likely to bring in more junior women. As one board chair stated:

It is certain that it will change, but it's because it's . . . people with different experiences, for example, effectively to arrive at forty percent one will have to name women who are not sixty or sixty-five but who will be forty-five .... It will automatically renew the profiles, and we will have younger people with different experiences. ${ }^{207}$

Board members also noted that male recruiting would be affected by the quota: boards would now be more selective in the men they chose to keep on the board. ${ }^{208}$ In the view of one board member, this heightened selectivity for males likely would eliminate more senior men, not by virtue of their age but because their more dated market experience would quickly become obsolete in a fastevolving marketplace. ${ }^{209}$ Perhaps not coincidentally, this participant suggested that those same senior men on the chopping block were more likely to also have retrograde understandings of women and their ability to contribute to corporate governance. $^{210}$

\section{F. Plus Ça Change}

Although many participants emphasized the diversity of newly added women, other participants pointed out the way in which recruiting processes continue to reproduce the perspectives of the men already serving on boards. As one senior female board member said:

[A]11 these [French] women have been made by the Grandes Ecoles of engineers, such as I'X, Centrale, all that, or they did Sciences-Po, they did the Ecole Nationale d'Administration, the grandes écoles of commerce. When you see the resumes ... we are in a system of Grandes Ecoles, with important backgrounds . . . . That is not at all diversified. It's for this that I say that the most important challenge for

206. Interview with $20 \mathrm{~F}$.

207. Interview with $23 \mathrm{M}$.

208. Interview with $31 \mathrm{M}$.

209. Id.

210. Interview with $23 \mathrm{M}$. 
French companies, it's the internationalizations of their boards. ${ }^{211}$

Recruiter interviews went some way to explain this self-reproducing dynamic: headhunters reported that to increase their chances of success, they choose people whose credentials look much like the current board members. ${ }^{212}$ In line with recent research, these responses suggest that, adding women, without other changes, will lead to decisions substantively similar to those by the board prior to their joining. ${ }^{213}$ At the same time, participants thought that the use of headhunters could institutionalize diversity as well, by shifting firms away from the use of private networks and toward the use of market participants for finding board members. ${ }^{214}$

In sum, board members suggested that the quota had in fact generated significant substantive differences by adding women, but not because the newly added members were women. Rather, their difference in other regards - their foreignness, their outsider status relative to the Grandes Ecoles networks, their relative lack of experience and fresh perspective, and their expertise in areas not traditionally represented on boards - contributed to a board's ability to think outside the box.

These board member observations are consistent with Page's observations that what matters about diversity are the alternative mental models, heuristics, frameworks, and perspectives that newly added members bring to collective decision-making. ${ }^{215}$ Particularly with regard to additional areas of expertise, newly added female members who see board issues from a more sociological perspective, or ecological perspective, or with greater sensitivity to stakeholders than shareholders, might potentially shake up (and thereby improve) traditional models by cross-fertilizing them with other perspectives.

\section{DISCUSSION AND CONCLUSION}

This preliminary qualitative study was designed to explore the link between sex and corporate governance and performance, from the perspective of those who currently sit on the boards of France's leading companies. Our results lead to a number of preliminary conclusions. First, in the board members' view, sex affirmatively affects the process of board decision-making, confirming earlier research. Women board members participate differently as board members than do men. In particular, participants observed that women asked more "naïve" questions, asked them more methodically, and asked the questions that men refrained from asking for fear of appearing foolish. Members noted that this style of questioning might well have been a function of the fact that newly added female members had less experience and were thus in need of additional

211. Interview with $7 \mathrm{~F}$.

212. Interview with $9 \mathrm{~F}$.

213. Magnier \& Rosenblum, supra note 28; Darren Rosenblum, Sex Regimes and the Reproduction of Corporate Elites (forthcoming) (on file with author).

214. Interview with $15 \mathrm{~F}$.

215. See generally PAGE, supra note 96. 
information.

The presence of women board members also appeared to reduce the combative tone of some board discussions, in the view of the board members themselves. Conversations were less power-driven and more open-ended; gallantry and civility were more prevalent.

Board members suggested, however, that increasing the number of women on the board did not affect substantive decision-making by boards. Even after being prompted by the interviewer, participants resisted the findings from earlier research that sex affected the board's substantive decision. More specifically, they rejected the idea that, as had been reported in a post-quota Norwegian study, women on boards had reduced the number of workforce layoffs because they were empathetic to labor. Participants did find women to be more empathetic to stakeholder interests, though they qualified this finding by attributing it to a more general corporate trend. Participants also suggested that post-quota boards might prove more likely to adopt policies that were pro-family, that promoted corporate social responsibility, and that aggressively recruited and hired women into positions of power and responsibility within the firm.

In our most important finding, board members suggested that any post-quota substantive differences could be attributed to the outsider status of newly added female members. Participants reported that such women were more likely to be foreign (because firms valued their experience and foreign connections), junior (because of the history of discrimination and the paucity of women with high level executive experience), and less likely to come from the Grandes Ecoles exclusive network. Moreover, according to the participants, firms were more likely to use the occasion of the quota as an opportunity to bring in women with additional areas of expertise - national, environmental, ecological, sociological, labor, etc. These findings suggest that such "two birds with one stone" opportunities to diversify might happen only during the accelerated window of adding members that the quota occasions.

Dhir's work on Norway's quota, which also draws from qualitative interviews of board members, provides support for these findings, though his study reaches a slightly different conclusion. Dhir's board member subjects reported that women participants affected the process of board decision making in much the same way that our participants reported - increasing the number of questions asked, expanding the range of perspectives as outsiders, and making process more systematic and orderly. In contrast to our participants, Dhir's subjects reported that these results were intimately connected to the sex of the newcomers, and not just their outsider or newcomer status, where our subjects reported these results as traceable to outsider or newcomer status rather than their sex.

Three factors may help to explain Dhir's subjects' responses. First, in contrast to Dhir, our study asked participants to differentiate between process and substance, in light of existing research that suggests gender might make a difference on the former without affecting the latter. Our interviews also pressed participants more aggressively to differentiate between outsider status and gender qua gender as the source of any potential effect on corporate decision-making. In our study, it was the "effect on substance" questions that occasioned French 
participants' reflections on the difference between sex as sex and sex as a marker for a wide range of outsider or newcomer attributes.

Second, Dhir's subjects appeared more willing to attribute these differences to sex than to non-sex factors like outsider or newcomer status. It may well be that Dhir's participants may have been essentializing attributes not intrinsically connected to sex, as Dhir himself acknowledges, though he ultimately rejects this possibility. When pressed, Dhir's participants had difficulty tracing differences in process to something other than newcomer or outsider status. Instead, participants used phrases like "female perspectives" and indirect references to outsider men still being men even if they were trained in other disciplines. In one instance, participants did speak of the "relational" perspective that women brought to the table, an idea that finds support in existing research. But by and large, participants referred more to outsider and newcomer traits when asked to explain why women affected decision-making.

Third, economic and cultural factors may distinguish the Norwegian corporate context from the French one. As Dhir noted, and as Darren Rosenblum has described previously in Feminizing Capital, ${ }^{216}$ Norway is a country where sex equality abounds. The quota's adoption was to remedy the fact that other aspects of society had far higher indices of equality than the corporate sector. In this regard, the Norwegian context differs markedly from the French one, in which sex equality indices lag substantially behind those of Norway. Such differences may account for Norwegian participants' willingness to attribute to gender what French participants attribute to outsider or newcomer status. Economic distinctions merit attention as well, as they too may have consequences for our distinct outcomes. Norway is a very wealthy but small country-its economy does not have the wide corporate diversity of larger economies. France is the world's fifth largest economy and its corporate sector is quite broad and increasingly (as we argue) globalized. ${ }^{217}$

In any event, it is not possible to yet discern from Dhir's results, nor from ours for that matter, whether any of the differences participants report are traceable to sex qua sex, to outsider status, or to some combination. ${ }^{218}$ As we

216. Darren Rosenblum, Feminizing Capital: A Corporate Imperitive, 6 BERKELEY BuS. L. J. 55 (2009).

217. Recent market capitalizations reflect this difference: Norway's publicly traded shares float for $\$ 250 \mathrm{~B}$, while France's are valued at $\$ 1.8 \mathrm{~T}$. The CAC 40 alone comprises $\$ 1.3 \mathrm{~T}$. Norway's exceptional levels of both gender equality and wealth may accord its firms an equally exceptional range of legitimate market behaviors. The size and vulnerability to market forces of France's firms may more closely approximate the market pressures that face firms across the Atlantic. In addition, board members in France are limited to serving on four boards, whereas Norway does not limit board participation, a factor that may have led Norwegian companies to limit their searches to women who already had board positions because they could do so.

218. It is also worth noting that our pools differ. Dhir's subject population included fifteen women and eight men, and that representation of women in his study may lead to a distinct result. Our study comes closer to parity, although even parity would constitute an overrepresentation of women given that women are still underrepresented on boards. 
conclude, further research is necessary to rigorously disentangle these factors more fully.

Indeed, our preliminary analysis generates a number of potentially testable hypotheses for future research: collective decision-making on corporate boards will be substantively improved by the addition of (i) foreign members; (ii) members with non-traditional areas of expertise like labor or the environment; (iii) members with less experience; (iv) members outside the traditional credentialing networks like the Grandes Ecoles. More generally, scholars should conduct research to determine whether sex quotas (or any other kind of quota) might produce improvements in substantive decision-making less because of some identity-based perspective that is biologically or socially based, and more because the structural differences that accompany recruiting a different group of people will inevitably diversify the mental models and perspectives of decisionmakers at the table. Future research will also, inevitably, have to grapple with the friction in-group dynamics introduced by such differences. As quotas spread and become more legitimate components of corporate governance, the implementation experiences and data will provide fruitful avenues for additional research. 